Amasya Ilahiyat Dergisi - Amasya Theology Journal

ISSN 2667-7326 | e-ISSN 2667-6710

Aralık / December 2020, 15: 275-319

\title{
Öğrencilerin Kitap Okuma Tutumları ile Kitap Okumanın DKAB Öğretim Programındaki Değerlere Etkisi Arasındaki İlişkinin İncelenmesi ${ }^{*}$
}

\author{
Ahmet KOÇ \\ Dr. Öğr. Üyesi, Yakın Doğu Üniversitesi, İlahiyat Fakültesi, \\ Din Eğitimi Ana Bilim Dalı \\ Assistant Professor, Near East University, Faculty of Theology, \\ Department of Religious Education \\ Lefkoşa, TRNC \\ ahmet.koc@neu.edu.tr \\ orcid.org/0000-0001-6165-4401
}

Makale Bilgisi / Article Information

Makale Türü / Article Types: Araştırma Makalesi / Research Article

Geliş Tarihi / Received: 16 Ağustos / August 2020

Kabul Tarihi / Accepted: 11 Eylül / September 2020

Yayın Tarihi / Published: 30 Aralık / December 2020

Yayın Sezonu / Pub. Date Season: Aralık / December

Sayı / Issue: 15 Sayfa / Pages: 275-319

Atıf / Cite as: Koç, Ahmet. “Öğrencilerin Kitap Okuma Tutumları ile Kitap Okumanın DKAB Öğretim Programındaki Değerlere Etkisi Arasındaki İlişkinin Incelenmesi [Investigation of the Relationship between Attitudes of Students' Reading Book and the Effect of Reading Books on the Values in the RCMK Curriculum]". Amasya Ilahiyat Dergisi-Amasya Theology Journal 15 (December 2020): 275-319.

https://doi.org/10.18498/amailad.781299.

Intihal / Plagiarism: Bu makale, en az iki hakem tarafından incelendi ve intihal içermediği teyit edildi. / This article has been reviewed by at least two referees and scanned via a plagiarism software.

* Bu araştırma, Yakın Doğu Üniversitesi Bilimsel Araştırmalar Etik Kurulu'nun 24.04.2020 tarih ve YDÜ/EB/2020/469 proje numaralı izni ile uygulanmıştır. 
276 | A. KOÇ / Öğrencilerin Kitap Okuma Tutumları ile Kitap Okumanın DKAB Öğretim Programındaki Değerlere Etkisi Arasındaki İlişkinin İncelenmesi

Copyright $\odot$ Published by Amasya Üniversitesi, İlahiyat Fakültesi / Amasya University, Faculty of Theology, Amasya, 05100 Turkey. All rights reserved. https://dergipark.org.tr/amailad.

\section{Investigation of the Relationship between Attitudes of Students' Reading Book and the Effect of Reading Books on the Values in the RCMK Curriculum}

\section{Abstract}

This study aims to determine the relationship between students' book reading attitudes and their views on the effect of their reading attitudes on values. In the study, both the level of the reading attitudes of the students was examined, and the extent to which the students' reading attitudes affect the values in the curriculum of the Religious Culture and Moral Knowledge (RCMK) lesson taught from class 4 to 12 in the Turkish Republic of Northern Cyprus (TRNC) was investigated. In particular, the study examined the effects of reading attitudes on students' values of "justice, sensitivity, solidarity, compassion, kindness, honesty, patience, love, respect, responsibility and solidarity". The reason why these values are the subject of the research is that they are the main values that are aimed to be taught in the TRNC RCMK program. In addition, compared to the values selected as research subjects and the ten values (justice, friendship, honesty, self-control, patience, respect, love, responsibility, patriotism, and benevolence) determined by the Ministry of Education of Republic of Turkey in 2017, both groups largely seems to overlap in a large extent.

The research was conducted in 2020 with 464 students studying in 11 schools selected from 53 secondary schools and high schools in TRNC with the maximum diversity method from purposeful sampling methods. The schools selected as sample consist of public/private schools from each region/type for the reflecting the demographic structure of the TRNC. This study was conducted with quantitative research method and the "Book Reading Attitude Scale" developed by Sarar-Kuzu and Doğan in order to determine students' attitudes towards reading books, and the "Effect of Reading Books on Values Scale" developed by the researcher to measure the effect of reading attitude on values were used together.

According to the research results; it was found that although both $15.9 \%$ of the students never read a book at all and $51.2 \%$ of them read less, they have a high attitude in the factor of "contributing to their personal/social development" and 
A. KOÇ / Investigation of the Relationship between Attitudes of Students' Reading Book and the Effect of Reading Books on the Values in the RCMK Curriculum I 277 have a moderate attitude in the factors of "interest/love" and "finding important/valuable". The students' opinions about the effect of reading books on values are at a high level. It was determined that the reading attitudes of female students were higher than male students. The views of students about the effect of reading books on values do not differ according to the gender variable. Both male and female students have a high level of attitudes towards this issue. When the data were analysed according to the variable of school type, it was determined that Anatolian High School, Theology College and College students scored are higher than other students in the factors of "the contribution of reading books to personal/social development", and "finding important/valuable". It can be said that the positive correlation between academic achievement and reading books is the reason for this result. In the "interest/love" factor for reading books, it was determined that the students of Theology College had a higher attitude than the students in other schools. It can be said that the reading activities at the school, the competitions and the easy access to the library played a role in the interest/love of the students of the Theology College. In addition, other variables such as "grade level, number of books they read in a year, having a study room/library/book corner at home, buying books from the school library, going to a library outside of school, buying books out of textbooks and reading digital books/magazines" caused to differentiated into the groups. It was determined that there is a positive and significant correlation between the students' reading attitudes and their views on the effect of reading books on values. Accordingly, it is possible to say that as the reading attitudes of the students increase; their views that reading books affect values also increase.

According to these results, the books to be selected according to their ages for students can gain them national and spiritual values. In addition, both the attitudes of reading can be increased and national/spiritual values can be taught through reading projects, competitions and activities to be organized in schools. In addition, qualitative research can be conducted to reveal how reading a book effects on which values.

Keywords: Religious Education, Values Education, Reading Book Attitude, Religious Culture and Moral Knowledge, Turkish Republic of Northern Cyprus. 
278 | A. KOÇ / Öğrencilerin Kitap Okuma Tutumları ile Kitap Okumanın DKAB Öğretim Programındaki Değerlere Etkisi Arasındaki İlişkinin İncelenmesi

\section{Öğrencilerin Kitap Okuma Tutumları ile Kitap Okumanın DKAB Öğretim Programındaki Değerlere Etkisi Arasındaki İlişkinin İncelenmesi} Öz

Bu araştırma, öğrencilerin kitap okuma tutumları ile kitap okuma tutumlarının değerlere etkisine yönelik görüşleri arasındaki ilişkiyi tespit etmeye yöneliktir. Araştırmada öğrencilerin hem kitap okuma tutumlarının ne düzeyde olduğu incelenmiş hem de Kuzey Kıbrıs Türk Cumhuriyeti'nde (KKTC) 4-12. sınıfları arasında okutulan Din Kültürü ve Ahlak Bilgisi Dersi (DKAB) öğretim programında öğretilmesi hedeflenen değerlerin, öğrencilerin kitap okuma tutumlarından ne düzeyde etkilendiği araştırılmıştır. Özellikle araştırmada kitap okuma tutumlarının öğrencilerin "adalet, duyarlılık, dayanışma, merhamet, nezaket, dürüstlük, sabır, sevgi, saygı, sorumluluk ve yardımlaşma" değerleri üzerinde bıraktığı etkiler ele alınmıştır. Bu değerlerin araştırmaya konu olmasının sebebi, KKTC DKAB programında öğretilmesi hedeflenen başlıca değerler olmalarıdır. Ayrıca araştırmada seçilen değerlerle Türkiye Cumhuriyeti Millî Eğitim Bakanlığının 2017 yılında belirlediği on kök değer (adâlet, dostluk, dürüstlük, öz denetim, sabır, saygı, sevgi, sorumluluk, vatanseverlik, yardımseverlik) karşılaştırıldığında, her iki grubun büyük oranda örtüştüğü görülmektedir.

Araştırma 2020 yılında, KKTC'de bulunan 53 ortaokul ve liseden amaçlı örnekleme yöntemlerinden maksimum çeşitlilik yöntemiyle seçilen 11 okul ve bu okullarda okuyan 464 öğrenci ile yapılmıştır. Örneklem olarak seçilen okullar, KKTC'nin demografik yapısını yansıtacak şekilde her bölgeden ve her okul türünden seçilen resmi/özel okullardan oluşmaktadır. Nicel araştırma yöntemiyle yapılan araştırmada, öğrencilerin kitap okumaya ilişkin tutumlarını belirlemek amacıyla Sarar-Kuzu ve Doğan tarafından geliştirilen "Kitap Okuma Tutum Ölçeği" ile kitap okuma tutumunun değerlere etkisini ölçmek amaciyla araştırmacı tarafından geliştirilen "Kitap Okumanın Değerlere Etkisi Ölçeği" kullanılmıştır.

Araştırma sonuçlarına göre; öğrencilerin \%15,9'unun hiç kitap okumayan, \%51,2'sinin az kitap okuyan özelliğinde olmalarına rağmen kitap okumanın "kişisel/toplumsal gelişimlerine katkı sağlama" faktöründe yüksek düzeyde, "ilgi/sevgi duyma" ile "önemli/değerli bulma" faktörlerinde orta düzeyde tutuma sahip oldukları tespit edilmiştir. Öğrencilerin kitap okumanın değerlere etkisine yönelik görüşleri ise yüksek düzeydedir. Kadın öğrencilerin kitap okuma tutumlarının erkek öğrencilere göre daha yüksek olduğu tespit edilmiştir. Öğrencilerin kitap okumanın değerlere etkisine yönelik görüşleri ise 
A. KOÇ / Investigation of the Relationship between Attitudes of Students' Reading Book and the Effect of Reading Books on the Values in the RCMK Curriculum I 279 cinsiyet değişkenine göre farklılık göstermemektedir. Tüm öğrencilerin bu konudaki tutumları yüksek düzeydedir. Okul türü değişkenine göre veriler analiz edildiğinde kitap okumanın "kişisel/toplumsal gelişime katkısı" ve kitap okumayı "önemli/değerli bulma" faktörlerinde ve kitap okumanın değerlere etkisi ölçeğinde, Anadolu Lisesi, İlahiyat Koleji ve Kolej öğrencilerinin diğer öğrencilerden daha yüksek puan verdikleri tespit edilmiştir. Özellikle akademik başarı ile kitap okuma arasındaki pozitif ilişkinin bunun sebebi olduğu söylenebilir. Kitap okumaya "ilgi/sevgi duyma” faktöründe İlahiyat Koleji öğrencilerinin diğer okullardaki öğrencilerden daha yüksek bir tutuma sahip oldukları tespit edilmiştir. Okuldaki kitap okuma etkinliklerinin, yarışmaların ve kütüphaneye erişimin kolay olmasının İlahiyat Koleji öğrencilerinin kitaba ilgi ve sevgi duymalarında rol oynadığı söylenebilir. Ayrıca "sınıf seviyesi, yılda okudukları kitap sayısı, evinde çalışma odası/kitaplık/kitap köşesine sahip olma, okul kütüphanesinden kitap alma, okul dışında kütüphaneye gitme, ders kitabı dışında kitap satın alma ve dijital kitap/dergi okuma" şeklindeki diğer değişkenlerin de gruplar arasında farklılığa sebep olduğu tespit edilmiştir. Öğrencilerin kitap okuma tutumları ile kitap okumanın değerlere etkisine yönelik görüşleri arasında pozitif ve anlamlı bir ilişki olduğu tespit edilmiştir. Buna göre öğrencilerin kitap okuma tutumları arttıkça kitap okumanın değerleri etkilediğine yönelik görüşlerinin de arttı̆̆ını söylemek mümkündür.

Bu sonuçlara göre öğrencilerin yaşlarına uygun olarak seçilecek kitaplarla millimanevi değerler kazandırılabilir. Okullarda düzenlenecek kitap okuma projeleri, yarışmalar ve etkinliklerle kitap okuma tutumları arttırılabilir ve milli-manevi değerlerin öğretilmesi sağlanabilir. Ayrıca kitap okumanın hangi değerleri, nasıl etkilediğini ortaya koymak için nitel araştırmalar yapılabilir.

Anahtar Kelimeler: Din Eğitimi, Değerler Eğitimi, Kitap Okuma Tutumu, Din Kültürü ve Ahlak Bilgisi, Kuzey Kıbrıs Türk Cumhuriyeti.

\section{Giriş}

"Okulda okumayı öğrenirsiniz, okuldan sonra ise öğrenmek için okursunuz" sözünde ifade edildiği gibi okuma, hayatın belli bir döneminde başlayıp biten bir etkinlik değil, insan hayatının tüm evrelerinde yeri olan önemli bir eğitim unsurudur. Okumayı öğrenen birey toplumun ortak hafızasına kitaplar vasitasıyla dâhil olur, ortak geçmişi tanır ve her okuma yaptığında bu kültür hafızası yenilenir (Arı, 
280 | A. KOÇ / Öğrencilerin Kitap Okuma Tutumları ile Kitap Okumanın DKAB Öğretim Programındaki Değerlere Etkisi Arasındaki İlişkinin İncelenmesi

2014, 39). Bir milletin sahip olduğu sosyal, kültürel, ekonomik ve bilimsel değerlerini kapsayan maddi ve manevi ögelerin bütünü olarak ifade edilen değerler, bireyin duygu, düşünce, tutum ve davranışlarını etkilediği gibi aynı zamanda çevreden etkilenen bir yapıya sahiptir.

Kuzey Kıbrıs Türk Cumhuriyeti (KKTC) hem ortaöğretim hem de yükseköğretim açısından yoğun bir öğrenci potansiyeline sahiptir. Küreselleşmenin ve teknolojik gelişmelerin bir sonucu olarak pek çok alanda olduğu gibi öğrencilerin tutum ve değerleri alanında da bir değişim süreci yaşanmaktadır. Teknolojik ilerlemenin her yaştan insanı etkilediği günümüzde, öğrenme ve kişisel gelişimini oluşturma safhasında olan gençlerin öğrenmenin temel unsurlarından biri olan kitap okuma tutumlarının ve buna bağlı olarak değerlerinin bu değişimden ne kadar etkilendiği önemli bir araştırma konusudur. Bu araştırmanın amacı, öğrencilerin kitap okuma tutumlarını ve kitap okumanın değerlere etkisine yönelik görüşlerini tespit etmektir. Özellikle araştırmada, KKTC'deki okulların 4-12. sınıfları arasında okutulan Din Kültürü ve Ahlak Bilgisi Dersi (DKAB) öğretim programında öğretilmesi hedeflenen değerlerin öğrencilerin kitap okuma tutumlarından hangi düzeyde ve nasıl etkilendiğinin incelenmesi hedeflenmiştir.

\section{Kavramsal Çerçeve}

\subsection{Kitap Okuma Tutumu}

Okuma, öğrencilerin dil, zihin, sosyal ve kültürel gelişimine katkı sağlayan alanların başında gelmektedir (Güneş - Susar Kırmızı, 2014, 197). Okuma, insanın bilgi edinme yollarından biri olup anlama becerilerinin en etkili ve kalıcı olanıdır. Birey, okuma vasıtasıyla ilgi duyduğu ve öğrenmek istediği bilgilere ulaşır, bu bilgilerden yola çıkarak yeni terkipler elde eder. Böylece kendi duygu ve düşünce dünyasını inşa etmiş olur (Deniz, 2015, 46). Okuma alışkanlığının kazanılmasında üç dönem: "çocukluk, gençlik ve yetişkinlik"; üç toplumsal kurum: "aile, okul ve çevre" ve üç birey türü: "ebeveyn, öğretmen ve arkadaş" etkili olmaktadır. Dönemler içinde özellikle öğrencilik döneminin geçirildiği çocukluk ve gençlik döneminin, bu alışkanlığ kazanmadaki önemi oldukça büyüktür (Keleş, 2006, 26).

Okuma becerisi ve okuma alışkanlığı olarak da ifade edilen okuma tutumu, yeni öğrenmelere temel oluşturarak öğrencilerin öğretim hayatının etkinleştirilmesinde önemli rol oynamaktadır (Sarar Kuzu - 
A. KOÇ / Investigation of the Relationship between Attitudes of Students' Reading Book and the Effect of Reading Books on the Values in the RCMK Curriculum I 281

Doğan, 2015, 776). Bireylerin okumaya karşı erken yaşlardan itibaren olumlu bir tutum geliştirmelerinin, akademik ve entelektüel yaşamlarının altyapısını pekiştirdiği, kelime hazinelerini ve anlama becerilerini geliştirdiği, okudukları kitapları daha iyi değerlendirmelerine yaradığı, sezme becerilerini ve başarılarını arttırdığı, böylece genel olarak öğrenmelerini de kolaylaştırdığı birçok araştırmacı ve eğitimci tarafından kabul görmektedir (Bulut vd., 2020, 77; Dilbaz, 2019, 9; Güneş - Susar Kırmızı, 2014, 201; Karatay vd., 2020, 92; Sarar Kuzu - Doğan, 2015, 775; Yaman - Süğümlü, 2010, 292).

Çağımızda öğretim araçlarının çok gelişip çeşitlenmesine rağmen okuma, öğrencilerin öğrenim hayatındaki önemini hâlâ korumaktadır (Yıldız - Keskin, 2016, 345). Çünkü teknolojinin akıl almaz bir hızla geliştiği dünyamızda meydana gelen yenilikleri takip etmek ve bu yeniliklere uyum sağlamak için kitap okumak, artık hobi olmaktan çıkıp bir zorunluluk hâlini almıştır (Calp, 2018, 899). Bireyin öğrendiği bilgilerin büyük bir kısmının kitap, ekran, grafik gibi okumaya dayalı metinler veya görseller aracığıyla olduğu kabul edilmektedir. Bu doğrultuda bireyin okuma ve okuduğunu anlama kapasitesinin üst düzeyde olması gerekmektedir (Arslan - Bıçakçıgil Özsoy, 2019, 732).

Okuma "mekanik, bilişsel, ruhsal" olmak üzere farklı boyutlara sahiptir. Tüm boyutlarıyla ele alındığında okumanın bir beceri olduğunu ve bu becerinin insanın nihai amacı olan kendini geliştirme ve kendini gerçekleştirme yolunda bir araç olduğu ifade edilebilir (Tüzer, 2016, 17). Okuma, insanı bir bütün olarak, bireysel ve toplumsal yönlerden etkilemektedir. Bedenî ve ruhi yönden sağlıklı gelişim gösterilebilmesi, duyarlık ve düşünmenin gelişebilmesi, kişilik ve insanlık oluşumunun gerçekleşebilmesi için gerekli en büyük faktör, okuma becerisini kazanmaktır (Karakullukçu, 2019, 13). Okuma, bireye yaşadığı hayatı ve diğer insanları tanıtan, bireyin ruh dünyasını zenginleştiren, kendisine toplumsal bir kimlik edinmesinde rol oynayan bir beceridir (Şahin vd., 2009, 184). Ülkemizde ve çevremizde yaşanan olaylar hakkında bilgi sahibi olmamızın, içinde bulunduğumuz yerlerin ve kimliğini taşıdığımız toplumun temel özelliklerini ve değerlerini bilmemizin ön koşulu kitap okumaktır (Yıldırım - Ceylan, 2018, 735).

\subsection{Değerler ve DKAB Dersinde Değerler Eğitimi}

Değer, bir ulusun sahip olduğu sosyal, kültürel, ekonomik ve bilimsel değerlerini kapsayan maddi ve manevi ögelerin bütünüdür 
282 | A. KOÇ / Öğrencilerin Kitap Okuma Tutumları ile Kitap Okumanın DKAB Öğretim Programındaki Değerlere Etkisi Arasındaki İlişkinin İncelenmesi

(Güncel Türkçe Sözlük, 20 Temmuz 2020). Değerler, insanı aynı zamanda toplumun bir parçası kılan unsurlardır. Toplumsal birlik ve beraberliğin sürdürülebilmesi, ancak değerlerin nesilden nesle aktarılması ile mümkündür. Değerlerin zayıfladığı veya bertaraf olduğu toplumlar, kültürel çözülme ve toplumsal ayrışma gibi toplumsal benliği tehdit eden sorunları yaşamaya mahkûmdurlar (Güneş, 2015, 1355).

Değerler eğitiminin eğitim-öğretim faaliyetlerinin önemli bir parçası olduğu yadsınamayacak bir husustur. Değerler eğitimi, insanlara değerleri temel düzeyde verme, birbirleriyle ilişiklerinde temel kuralları öğretme ve öğrencilere değerler hususunda temel prensipleri kavramalarını sağlamak için gerekeni yapma sürecidir (Göksu, 2018, 36). Değerler eğitiminin amac1, çocuğun doğuştan getirdiği en iyi tarafı ortaya çıkarmak; kişiliğinin her yönüyle gelişmesini sağlamak, insanî mükemmelliğe ulaşmasına yardımcı olmak; bireyi ve toplumu kötü ahlâktan korumak ve kurtarmak; iyi ahlâkla donatmak ve devamını sağlamaktır (Göksu, 2018, 37). Okul hayatı süresince öğrenilen bilgilerin büyük bir kısmının hem kullanım süresi hem de bireyin tutum ve davranışları üzerindeki etkisi son derece kısıtlı kalırken, değerler ile ilgili öğrenmelerin, hayatın tüm safhalarında önemini ve etkisini hem korumakta hem de devam ettirmekte olduğu ifade edilmektedir (Gör, 2013, 54).

KKTC Milli Eğitim Yasası'nın "genel amaçlar", "ulusal ahlak ve kültürün geliştirilmesi", "demokrasi bilincinin geliştirilmesi" ve "amaç ve görevler" bölümlerinde toplumsal, insani, ahlaki, manevi ve kültürel değerlerin öğretilmesi bir hedef ve görev olarak belirtilmiştir (KKTCMEY, 23 Mayıs 1986). Okulların yüklendiği bu sorumluluğu omuzlayan paydaşlardan biri de DKAB dersleridir. Bu derslerin öğretim programlarının öğrencilerin değerleri kazanıp geliştirmesi açısından üstlendiği rol, son yıllarda giderek artmaktadır (Göksu, 2018, 245). Bu amaç ve hedef doğrultusunda KKTC'deki okulların 4-12. sinifları arasında okutulan DKAB öğretim programında 44 değerin öğretilmesi hedeflenmiştir. Bunlar arasında farklı sınıf kademelerinde üzerinde en sık durulan değerler; "adalet, barış, duyarlılık, dayanışma, güven, merhamet, nezaket, dürüstlük, sabır, sevgi, saygl, sorumluluk ve yardımlaşma" değerleri olmuştur. Her bir konuda doğrudan verilecek değerler belirlenmiş ve nasıl verilecekleri, öğretim değerlerine ilişkin yaklaşımlar ile birlikte öğretim programında açılanmıştır (KKTCDKAB, 2018). 
A. KOÇ / Investigation of the Relationship between Attitudes of Students' Reading Book and the Effect of Reading Books on the Values in the RCMK Curriculum I 283

\subsection{Araştırmanın Amacı ve Önemi}

Tutum; "bireyin davranışların yönlendirmede önemli bir güce sahip, sonradan kazanılmış duygu, düşünce ve eğilimler" dir (Çelik, 2015, 276). Öğrencilerin hem kitap okuma tutumlarının gelişmesinde hem de değer yargılarının oluşmasında, çocukluk ve gençlik dönemi ile okul ve öğretmen etkisi çok önemli bir rol oynamaktadır. Öğrencilerin bu dönemdeki kitap okuma tutumlarının ve bu tutumlarının değerlere etkisinin incelenmesi kaliteli bir eğitim, başarılı bir öğrenci ve gelişmiş bir ülke hedefi için önemlidir. Ayrıca öğrencilerin okuma tutumlarının tespit edilmesiyle birlikte okumaya ilişkin olası sorunlar da belirlenmiş olacak ve bu sayede bu sorunlara çözümler bulunabilecektir. Bu nedenle okuma alışkanlığını geliştirme sürecinde öğrencilerin okumaya ilişkin geliştirdikleri tutumların tespit edilmesi ve bu tutumun değerlere etkisinin ölçülmesi önem arz etmektedir.

Literatüre bakıldığında okuma tutumu ve değerler ile ilgili ayrı ayrı pek çok çalışma bulunmaktadır. Kitap okuma ile ilgili çalışmalar, okul öncesinden üniversiteye kadar eğitimin her kademesindeki öğrencilerin okuma tutum, beceri ve alışkanlıklarının ölçülmesi amacıyla gerçekleştirilmiştir (Elbir - Bağcl, 2013). Değerler ile ilgili araştırmalar hem genel değerleri inceleyen hem de bir değeri ele alan araştırmalar şeklinde yapılmıştır (Baş - Bayhan, 2012; Dündar - Hareket, 2016; Metin - Metiner, 2019). Ancak kitap okuma tutumu ile değerler arasındaki muhtemel ilişkiyi inceleyen bir araştırmaya rastlanmamıştır. Sadece bir araştırmada; "kitap okuma faaliyetlerinin değerler eğitimine olumlu katkısı hususu araştırma kapsaminda olmamasına rağmen görüşme sırasında ulaşılan bulgulardandır. Elde edilen sonuca göre öğrencilerin kitap okumalarının teşvik edilmesinin değerler eğitimi faaliyetlerine olumlu katkı sağlayacă̆ı göz ardı edilmemesi gereken bir durumdur." şeklinde bir sonuç ifadesi yer almakta ve araştırmacının önerilerinden birisi de bu konunun araştırılması üzerinedir (Göksu, 2018, 246). Bu bakımdan bu araştırmanın literatürde önemli bir boşluğu dolduracağı ifade edilebilir.

$\mathrm{Bu}$ araştırmanın amacı, öğrencilerin kitap okuma tutumlarını ve kitap okumanın değerlere etkisine yönelik görüşlerini tespit etmektir. Öğrencilerin kitap okuma tutumları ve kitap okuma tutumlarının değerlere etkisine yönelik görüşleri demografik özelliklere göre analiz edilmiştir. Ardından kitap okuma tutumları ile kitap okumanın değerlere etkisine yönelik öğrencilerin görüşleri arasındaki ilişkinin ne 
284 | A. KOÇ / Öğrencilerin Kitap Okuma Tutumları ile Kitap Okumanın DKAB Öğretim Programındaki Değerlere Etkisi Arasındaki İlişkinin İncelenmesi

düzeyde olduğunun tespit edilmesi amaçlanmıştır. Kitap okuma tutumlarının öğrencilerin "adalet, duyarlılık, dayanışma, merhamet, nezaket, dürüstlük, sabır, sevgi, saygl, sorumluluk ve yardımlaşma" değerleri üzerinde bıraktığı etkiler ele alınmıştır. Bu değerlerin araştırmaya konu olmasının sebebi, KKTC DKAB programında öğretilmesi hedeflenen başlıca değerler olmalarıdır. Ayrıca araştırmada seçilen değerlerle Türkiye Cumhuriyeti Millî Eğitim Bakanlığının 2017 yılında belirlediği on kök değer (adâlet, dostluk, dürüstlük, öz denetim, sabır, saygı, sevgi, sorumluluk, vatanseverlik, yardımseverlik) karşılaştırıldığında, her iki grubun büyük oranda örtüştüğü görülmektedir (TTKB, 18 Temmuz 2017).

\subsection{Araştırmanın Problemi}

$\mathrm{Bu}$ araştırmada öğrencilerin genel olarak aile, okul ve toplumda kazandıkları, özel olarak ise DKAB dersinin bir kazanımı olarak elde ettikleri değerlerin, kitap okuma tutumlarıyla değişip değişmediği incelenmiştir. Araştırmanin problem cümlesi şu şekildedir: “Öğrencilerin kitap okuma tutumları ve kitap okumanın değerleri etkilemesine yönelik görüşleri ne düzeydedir?" Alt problemler ise şu şekildedir:

Öğrencilerin kitap okuma tutumları ne düzeydedir?

Öğrencilerin kitap okuma tutumlarının değerlere etkisine yönelik görüşleri ne düzeydedir?

Öğrencilerin kitap okuma tutumları ve kitap okuma tutumlarının değerlere etkisine yönelik görüşleri "cinsiyeti, okul türü, sınıf seviyesi, evde çalışma odasının olması, evde kitaplığın olması, yıllık kitap okuma sayısı, okul kütüphanesinden kitap almasl, kütüphaneye gitmesi, kitap satm almasl, teknolojik araçlara sahip olması ve e-kitap okuması" değişkenlerine göre farklılaşmakta midır?

Öğrencilerin kitap okuma tutumları ile kitap okumanın değerlere etkisine yönelik görüşleri arasında ilişki var mıdır?

\section{Yöntem}

\subsection{Araştırma Modeli}

Araştırma, nicel araştırma yöntemine göre gerçekleştirilmiştir. Araştırma konusu olan öğrencilerin kitap okuma tutumları ile kitap okumanın değerlere etkisine yönelik görüşleri karşılaştırma türü ilişkisel tarama yolu ile durum tespiti yapılmıştır. Tarama modeli geçmişteki veya mevcut durumu var olduğu şekliyle betimleyen araştırma modelleridir (Büyüköztürk vd., 2019, 14). Öğrencilerin kitap okuma 
A. KOÇ / Investigation of the Relationship between Attitudes of Students' Reading Book and the Effect of Reading Books on the Values in the RCMK Curriculum I 285

tutumları ve kitap okumanın değerlere etkisine yönelik görüşlerini ölçmek için nicel veri toplama araçları kullanılmıştır.

\subsection{Evren ve Örneklem}

Araştırmanın evrenini 2019-2020 eğitim ve öğretim yılında KKTC'de bulunan tüm ortaokul ve lise öğrencileri oluşturmaktadır. KKTC Milli Eğitim ve Kültür Bakanlığı'ndan alınan bilgiye göre bu sayı toplam $22345^{\prime}$ dir. KKTC'de bulunan 53 ortaokul ve liseden amaçlı örnekleme yöntemlerinden maksimum çeşitlilik yöntemiyle seçilen 11 okul ve bu okullarda okuyan toplam 464 öğrenci araştırma örneklemini oluşturmaktadır. Örneklem olarak seçilen okullar, KKTC'nin demografik yapısını yansıtacak şekilde her bölgeden ve her okul türünden seçilen resmi/özel okullardan oluşmaktadır. Bu bağlamda çalışma KKTC'nin beş ayrı ilçesinde ve yedi ayrı okul türünde uygulanmıştır. Örneklem grubunun evreni temsil gücünü hesaplamada 0,95 güven düzeyi ve 0,05 sapma miktarı olarak kabul edilmiştir. Yapılan işlem sonucunda bu çalışmanın 22345 birimlik olan evreni temsil edecek olan minimum örneklem sayısı 378 olarak hesaplanmıştır (Büyüköztürk vd., 2019, 98). Elde edilen bu sonuca göre araştırmadaki 464 birimden oluşan örneklemin, çalışma evrenini temsil gücü için yeterli olduğu söylenebilir. Araştırma katılımcılarının demografik özellikleri Tablo 1'de verilmiştir:

Tablo 1. Araştırmada Yer Alan Katılımcıların Demografik Özellikleri

\begin{tabular}{llll}
\multicolumn{1}{c}{ Değişken } & & $\mathrm{N}$ & $\%$ \\
\hline \hline \multirow{2}{*}{ Cinsiyet } & Kadın & 235 & 50,6 \\
\cline { 2 - 4 } & Erkek & 229 & 49,4 \\
\hline \hline \multirow{4}{*}{ Okul Türleri } & Resmi Ortaokul & 85 & 18,3 \\
\cline { 2 - 4 } & Özel Ortaokul & 48 & 10,3 \\
\cline { 2 - 4 } & Lise & 45 & 9,7 \\
\cline { 2 - 4 } & Anadolu Lisesi & 61 & 13,1 \\
\cline { 2 - 4 } & Meslek Lisesi & 56 & 12,1 \\
\cline { 2 - 4 } & İlahiyat & 110 & 23,7 \\
\cline { 2 - 4 } Sınıf Düzeyi & Kolej & 59 & 12,7 \\
\hline \hline \multirow{2}{*}{ Kendisine Ait Çalışma Odası } & Ortaokul & 202 & 43,5 \\
\cline { 2 - 4 } & Lise & 262 & 56,5 \\
\hline \hline
\end{tabular}


286 | A. KOÇ / Öğrencilerin Kitap Okuma Tutumları ile Kitap Okumanın DKAB Öğretim Programındaki Değerlere Etkisi Arasındaki İlişkinin İncelenmesi

\begin{tabular}{|c|c|c|c|}
\hline \multirow{2}{*}{$\begin{array}{l}\text { Kendisine Ait Kitaplık/Kitap Köşesi } \\
\text { Var mı? }\end{array}$} & Evet, var & 339 & 73,1 \\
\hline & Hayır, yok & 125 & 26,9 \\
\hline \multirow{4}{*}{ Yılda Okuduğu Kitap Sayısı } & Hiç okumadım. & 74 & 15,9 \\
\hline & 1-5 kitap & 238 & 51,2 \\
\hline & 6-19 kitap & 112 & 24,2 \\
\hline & 20+ kitap & 40 & 8,7 \\
\hline \multirow{2}{*}{$\begin{array}{lcc}\text { Şimdiye } & \text { Kadar } & \text { Okul } \\
\text { Kütüphanesinden Kitap Aldınız m }\end{array}$} & Evet, aldım. & 291 & 62,7 \\
\hline & Hayır, almadım & 173 & 37,3 \\
\hline \multirow{2}{*}{$\begin{array}{l}\text { Okul Dışındaki Bir Kütüphaneye } \\
\text { Gittiniz mi? }\end{array}$} & Evet, gittim. & 225 & 48,5 \\
\hline & Hayır, gitmedim. & 239 & 51,5 \\
\hline \multirow{2}{*}{$\begin{array}{l}\text { Ders Kitabı Dışında Bir Kitap Satın } \\
\text { Aldınız mı? }\end{array}$} & Evet, aldım. & 377 & 81,3 \\
\hline & Hayır, almadım. & 87 & 18,7 \\
\hline \multirow{2}{*}{ Dijital Dergi/Kitap Okudunuz mu? } & Evet, okudum. & 261 & 56,3 \\
\hline & Hayır, okumadım. & 203 & 43,7 \\
\hline TOPLAM & & 464 & \%100 \\
\hline
\end{tabular}

Katılımcların demografik özelliklerine bakıldığında cinsiyetlerine göre dengeli bir dağılım olduğu (\%50,6-\%49,4) görülmektedir. Yedi ayrı okul türünde gerçekleştirilen bu araştırmada katılımcılara okul türlerine göre bakıldığında dengeli bir dağılım olduğu; sınıf düzeylerine göre ise ortaokulda okuyan öğrencilerin $\% 43,5$, lisede okuyan öğrencilerin $\% 56,5$ olduğu görülmektedir. Öğrencilerin büyük çoğunluğunun evlerinde çalışma odası $(\% 78,7)$ ve kitaplık/kitap köşesi $(\% 73,1)$ olduğu görülmektedir. Bireylerin kitap okuma durumları hiç okumayanlar için "okuyucu olmayan", yılda 1-5 arası kitap okuyanlar için "az okuyan", yılda 6-19 arası kitap okuyanlar için "orta düzeyde okuyan" ve yılda 20'den fazla okuyanlar için ise "çok okuyan" nitelendirmesi yapılmaktadır (Karakullukçu, 2019, 16). Öğrencilerin \%15,9'unun yılda hiç kitap okumadığı, yarısının $(\% 51,2)$ az kitap okuyan kategorisinde olduğu, $24,2^{\prime}$ sinin orta düzeyde bir okuyucu olduğu ve \%8,7'sinin çok okuyan grubunda olduğu görülmektedir. Öğrencilerin büyük çoğunluğunun $(\% 62,7)$ okul kütüphanesinden kitap aldığı ancak yarısından fazlasının $(\% 51,5)$ okul dışında bir kütüphaneye gitmediği ortaya çıkmıştır. Öğrencilerin çok önemli bir kısmı $(\% 81,3)$ ders kitabı dışında bir kitap satın almıştır. Öğrencilerin \%56,3'ünün dijital kitap/dergi okuduğu tespit edilmiştir. 
A. KOÇ / Investigation of the Relationship between Attitudes of Students' Reading Book and the Effect of Reading Books on the Values in the RCMK Curriculum I 287

\subsection{Veri Toplama Araçları}

Okuma Tutum Ölçeği: Öğrencilerin kitap okumaya ilişkin tutumlarını belirlemek amacıyla geliştirilen Okuma Tutum Ölçeği (OTÖ) Sarar-Kuzu ve Doğan tarafından geliştirilmiştir. 38 maddeden oluşan beşli Likert tipi bir ölçeğin analizinde alınan yüksek puanlar öğrencinin okuma tutumunun olumlu ve yüksek olduğunu göstermektedir. Tutumların bileşenleri açısından maddelerin dağılımına bakıldığında; 21 tanesinin bilişsel, 11 tanesinin duyuşsal, 6 tanesinin de davranışsal tutumları ölçer özellikte olduğu görülmektedir. Ölçeğe uygulanan madde analizi sürecinde gerçekleştirilen madde-ölçek toplam puanı korelasyon analizi sonuçları, bütün maddelerin toplam puanlar ile gösterdiği korelasyonun 0,20 ' den büyük olduğunu ve bütün maddelerin toplam puanlar ile pozitif korelasyon gösterdiğini ortaya koymuştur. Ölçeğin faktör analizi öncesindeki Kaiser-Meyer-Olkin değeri 0,923, Barlett değeri ise 0,001 olarak tespit edilmiştir. Bu değerler ölçeğin faktör analizi için uygun olduğunu göstermektedir. Ölçek, kişisel ve sosyal gelişime katkı(19 madde), ilgi ve sevmek(14 madde), önem/değerli bulma (5 madde) olmak üzere üç faktörden oluşmaktadır. Ölçeğin faktör yük değerleri 0,472-0,801 arası, toplam açıkladığı varyans \%45 olarak tespit edilmiştir (Sarar Kuzu - Doğan, 2015, 779). Cronbach alfa değeri ölçeğin tamamı için 0,877, alt boyutları için sırasıyla 0,907, 0,839 ve $0,718^{\prime}$ dir. Madde toplam korelasyonları ise 0,419 ile 0,652 arasindadir. Ölçeğin tamamı ve alt boyutları için "güvenilir ölçek" ifadesi kullanılabilir (Büyüköztürk, 2020, 83). Bu sonuçlar ölçeğin araştırmada geçerli ve güvenilir bir ölçme aracı olarak kullanılabileceğini göstermektedir.

Kitap Okumanın Değerlere Etkisi Ölçeği: Kitap okuma tutumunun değerlere etkisini ölçmek amacıyla araştırmacı tarafından geliştirilen ölçek, "düzenli kitap okumak, kişinin başkalarının kendisinden farklı düşüncelerine karşı daha anlayışlı olmasını sağlar." şeklindeki sorulardan oluşmaktadır. Ölçek maddeleri ekte sunulmuştur. Ölçekte KKTC DKAB öğretim programında üzerinde en sık durulan değerler olan "adalet, duyarlılık, dayanışma, merhamet, nezaket, dürüstlük, sabır, sevgi, saygı, sorumluluk ve yardımlaşma" değerlerinin ölçülmesi hedeflenmiş ve soru havuzu buna göre oluşturulmuştur. İlk olarak 16 sorudan oluşan bir soru havuzu oluşturulmuş ve eğitim alanında uzman iki akademisyenden görüş alınmıştır. Araştırmacı bunun ardından ölçekte 
288 | A. KOÇ / Öğrencilerin Kitap Okuma Tutumları ile Kitap Okumanın DKAB Öğretim Programındaki Değerlere Etkisi Arasındaki İlişkinin İncelenmesi

yer alan soruların net ve anlaşılır olup olmadığı, katılımcılara aynı şeyi ifade edip etmediği ve araştırmanın amacına ne kadar hizmet edeceğini belirlemek amaciyla 50 öğrenci ile pilot uygulama yapmıştır. Uygulamadan elde edilen verilerle yapılan faktör analizi sonucunda, faktör yük değerleri $0,40^{\prime}$ ın altında olan ve değerlerinin negatif olduğu tespit edilen maddeler analizden çıkartılmıştır. Birinci uygulamanın analizi sonucunda 10 maddeli ve tek boyutlu bir yapı elde edilmiştir. Araştırmanın ana uygulaması ise pilot uygulamadan farklı 464 kişilik bir örneklem grubu ile yapılmıştır. Ölçeğin tek boyutlu olduğunu gösteren scree plot grafiği Şekil 1'de verilmiştir:

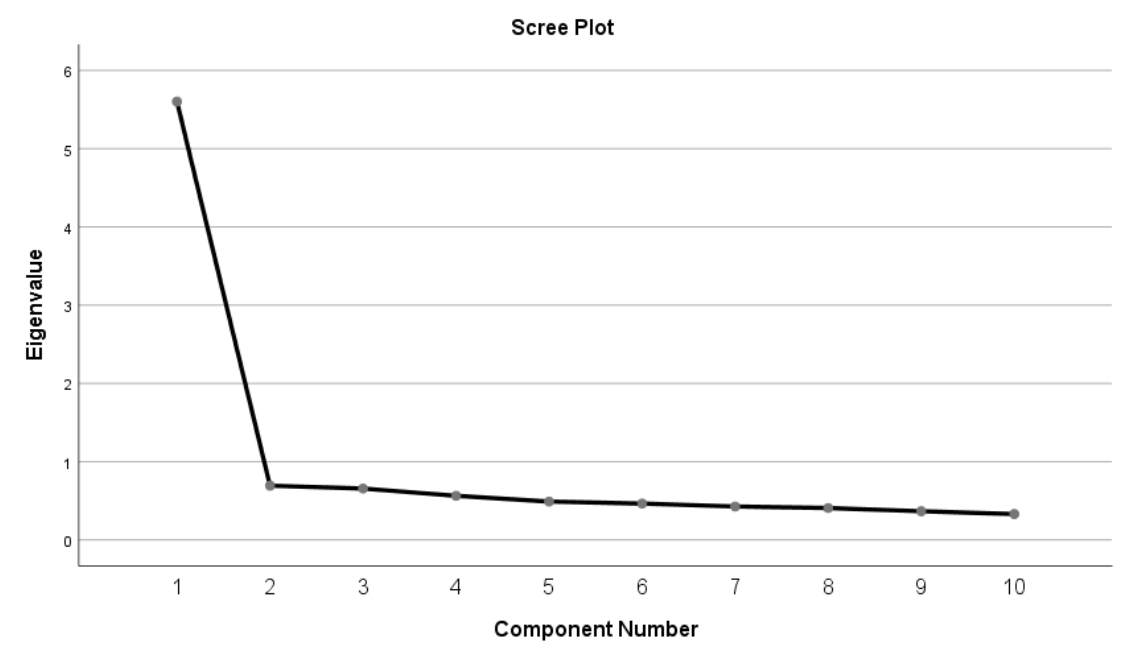

Şekil 1: Kitap Okumanın Değerlere Etkisi Ölçeğinin Scree Plot Grafiği

Şekil 1'de görüldüğü üzere öğrencilerin kitap okuma tutumlarının değerlere etkisine yönelik görüşlerini ölçmek için geliştirilen ölçek 10 maddeden oluşmaktadır. Beşli Likert tipi bir yapıda hazırlanan ölçek tek boyuttur. Öncelikle verilerin faktör analizine uygun olup olmadığ Bartlett Küresellik Testi ve Kaiser-Meyer-Olkin (KMO) örneklem yeterlik testi ile ölçülmüştür. Kaiser-Meyer-Olkin değeri 0,944, Barlett değeri ise 0,000 olarak 0,001'den küçük çıkmıştır. Bu değerler ölçeğin faktör analizi için mükemmel seviyede olduğunu göstermektedir (Yurtkoru vd., 2018, 80). Ölçeğin faktör yük değerleri 0,676-0,796 arası, toplam açıkladığı varyans \%56 olarak tespit edilmiştir. Cronbach alfa değeri 0,912'dir. Madde toplam korelasyonları ise 0,601 ile 0,733 
A. KOÇ / Investigation of the Relationship between Attitudes of Students' Reading Book and the Effect of Reading Books on the Values in the RCMK Curriculum I 289

arasındadır. Ölçek için "güvenilir" ifadesi kullanılabilir (Büyüköztürk, 2020, 83). Bu sonuçlar ölçeğin araştırmada geçerli ve güvenilir bir ölçme aracı olarak kullanılabileceğini göstermektedir.

\subsection{Verilerin Toplanması}

Araştırma için Yakın Doğu Üniversitesi Bilimsel Araştırmalar Etik Kurulu'nun 24.04.2020 tarih ve YDÜ/EB/2020/469 proje numaralı etik izni alınmıştır. Milli Eğitim ve Kültür Bakanlığı'ndan alınan iznin ardından okul yönetimleri ile iletişime geçilmiştir. 2020 yılında gerçekleştirilen bu araştırma, katılımcıların yazılı onayları alınarak gerçekleştirilmiştir.

\subsection{Verilerin Analizi}

Verilerin analizi için SSPS 25.0 programı kullanılmıştır. Öğrencilerin kitap okuma tutumlarının ve değerlere etkisinin ölçülmesi amacıyla aritmetik ortalamalar elde edilmiştir. Her iki veri toplama aracında kullanılan 5'li Likert ölçeği, 1'den 5'e kadar olan değerlendirme ölçeği olduğundan beş eşit parçaya bölünerek her seçeneğe karşılık gelen puan aralığı tespit edilmiştir. Buna göre; 1,00-1,79 arası "hiç", 1,802,59 aras1 "az", 2,60-3,39 aras1 "orta", 3,40-4,19 aras1 "yüksek" ve 4,205,00 arası ise "tam" olarak değerlendirilmiştir. Çalışmada her alt probleme uygun istatistiksel yöntemler kullanılmıştır.

Grup sayısı iki olan demografik faktörler arasındaki farklılıkları tespit etmek amacıyla $t$ testi kullanılmıştır. Grup sayısı ikiden çok olan öğelerin ilk olarak sorulara verdikleri cevaplar bakımından homojen dağılıp dağılmadıklarını tespit etmek amacıyla Levene testi kullanılmıştır. Homojen dağılan gruplarda Anova testi kullanılarak gruplar arasında farklılı̆̆ın 0,05 (\%95) anlamlılık seviyesinde olup olmadığ1 incelenmiştir. Homojen dağılım göstermeyen gruplarda ise farklılık testi olarak Anova testinin alternatifi olan Brown-Forsyth testi kullanılmıştır. Anlamlı farklılık tespit edilen gruplarda hangi grupların diğerlerinden ayrıştığını belirlemek amacıyla LSD testi uygulanmıştır. Öğrencilerin kitap okuma tutumları ile kitap okumanın değerlere etkisine yönelik görüşleri arasındaki ilişkiyi tespit etmek için ise korelasyon analizi yapılmıştır. 
290 | A. KOÇ / Öğrencilerin Kitap Okuma Tutumları ile Kitap Okumanın DKAB Öğretim Programındaki Değerlere Etkisi Arasındaki İlişkinin İncelenmesi

\section{Bulgular}

3.1 Öğrencilerin Kitap Okuma Tutumları ve Kitap Okumanın Değerlere Etkisine Yönelik Görüşleri

Öğrencilerin kitap okuma tutumlarını ve kitap okumanın değerlere etkisine yönelik görüşlerini belirlemek için yapılan analizlerin sonuçları tablolar halinde gösterilmiştir. Araştırmada kullanılan kitap okuma tutum ölçeğine ve kitap okumanın değerlere etkisi ölçeğine öğrencilerin verdiği toplam puanları gösteren veriler Tablo 2'de verilmiştir:

Tablo 2. Öğrencilerin Kitap Okuma Tutumları ve Kitap Okumanın Değerlere Etkisine Yönelik Görüşlerine Ait Toplam Puanları

\begin{tabular}{|c|c|c|c|c|c|c|c|}
\hline Ölçek & Faktör & $\mathrm{N}$ & Min. & Max. & $\overline{\mathrm{X}}$ & SD & Değer \\
\hline \multirow{3}{*}{$\begin{array}{l}\text { Kitap } \\
\text { Okuma } \\
\text { Tutum } \\
\text { Ölçeği }\end{array}$} & $\begin{array}{l}\text { Kişisel/Toplumsal } \\
\text { Gelişime Katkı }\end{array}$ & 464 & 1,00 & 5,00 & 3,66 & 0,824 & Yüksek \\
\hline & İlgi ve Sevmek & 464 & 1,00 & 5,00 & 3,16 & 0,843 & Orta \\
\hline & $\begin{array}{l}\text { Önemli-Değerli } \\
\text { Bulma }\end{array}$ & 464 & 1,00 & 5,00 & 3,03 & 1,060 & Orta \\
\hline \multicolumn{2}{|c|}{$\begin{array}{c}\text { Kitap Okumanın Değerlere } \\
\text { Etkisi Ölçeği }\end{array}$} & 464 & 1,00 & 5,00 & 3,51 & 1,028 & Yüksek \\
\hline
\end{tabular}

Tablo 2'de verilen sonuçlara göre öğrenciler kitap okuma tutum ölçeğinin kişisel ve toplumsal gelişime katkı faktörüne $\bar{X}=3,66$ puan, ilgi ve sevmek faktörüne $\bar{X}=3,16$ puan, önemli ve değerli bulma faktörüne ise $\bar{X}=3,03$ puan vermişlerdir. Bu sonuçlara göre öğrenciler kitap okumanın kişisel ve toplumsal gelişimlerine katkı sağladığını yüksek düzeyde değerlendirirlerken, kitap okumaya olan ilgi ve sevgileri ile kitap okumayı önemli ve değerli bulmaları orta düzeydedir. Diğer bir ifadeyle öğrenciler kitap okumanın kişisel ve toplumsal gelişimlerine yapacağ katkının farkında olmalarına rağmen kitap okumaya aynı düzeyde ilgi, sevgi, önem ve değer göstermemektedirler. Öğrencilerin kitap okumanın değerlere etkisine yönelik görüşleri $\overline{\mathrm{X}}=3,51$ puanla yüksek düzeydedir. Bu sonuca göre öğrenciler kitap okumanın değerlere etki ettiğini düşünmekteler ve bu konudaki görüşleri yüksek düzeydedir. Bu sonuçlar öğrencilere genel anlamda kitap okuma bilincinin verildiği, 
A. KOÇ / Investigation of the Relationship between Attitudes of Students' Reading Book and the Effect of Reading Books on the Values in the RCMK Curriculum I 291 ancak bu konuda daha yapılması gerekenlerin olduğu şeklinde yorumlanabilir.

Literatürdeki çalışmalarda benzer ve farklı sonuçlar görülmektedir. Lise öğrencilerine yönelik bir araştırmanın sonuçlarına göre öğrencilerin kitap okuma alışkanlıklarının yüksek olduğu (Yıldırım - Ceylan, 2018, 743), başka bir araştırmada öğrencilerin günde bir saat kitap okudukları (Demir, 2016, 53), ortaokul öğrencilerine yapılan bir araştırma da öğrencilerin genel anlamda okuma alışkanlığına ilişkin tutumlarının orta ve üst düzeyde olduğu ifade edilmektedir (Balcı, 2009, 291). Üniversite öğrencilerine yönelik yapılan bir araştırmada öğrencilerin kitap okuma tutumlarının yüksek düzeyde olduğu ve bu durumun öğrencilerin üniversiteye gelmeden önce okudukları okullarda kazandıkları alışkanlıklara bağlanmaktadır (Arslan Bıçakçıgil Özsoy, 2019, 743).

3.2 Cinsiyet Değişkenine Göre Öğrencilerin Kitap Okuma Tutumları ve Kitap Okumanın Değerlere Etkisine Yönelik Görüşleri

Öğrencilerin cinsiyetlerine göre kitap okuma tutumlarını ve kitap okumanın değerlere etkisine yönelik görüşlerini gösteren veriler Tablo 3'te sunulmuştur:

Tablo 3. Cinsiyet Değişkenine Göre Öğrencilerin Kitap Okuma Tutumları ve Kitap Okumanın Değerlere Etkisine Yönelik Görüşleri

\begin{tabular}{|c|c|c|c|c|c|c|c|}
\hline Ölçek & Faktör & Cinsiyet & $\mathrm{N}$ & $\overline{\mathrm{X}}$ & SD & $\mathrm{t}$ & $\mathrm{P}$ \\
\hline \multirow{6}{*}{$\begin{array}{l}\text { Kitap } \\
\text { Okuma } \\
\text { Tutum } \\
\text { Ölçeği }\end{array}$} & Kişisel/Toplumsal & Kadın & 235 & 3,76 & 0,866 & \multirow{2}{*}{2,453} & \multirow{2}{*}{$0,015^{*}$} \\
\hline & Gelişime Katk1 & Erkek & 229 & 3,57 & 0,768 & & \\
\hline & \multirow{2}{*}{ İlgi ve Sevmek } & Kadın & 235 & 3,30 & 0,880 & \multirow{2}{*}{3,648} & \multirow{2}{*}{$0,000^{* *}$} \\
\hline & & Erkek & 229 & 3,02 & 0,780 & & \\
\hline & \multirow{2}{*}{$\begin{array}{l}\text { Önemli-Değerli } \\
\text { Bulma }\end{array}$} & Kadın & 235 & 3,16 & 1,086 & \multirow{2}{*}{2,608} & \multirow{2}{*}{$0,009^{* *}$} \\
\hline & & Erkek & 229 & 2,90 & 1,018 & & \\
\hline \multirow{2}{*}{\multicolumn{2}{|c|}{$\begin{array}{c}\text { Kitap Okumanın Değerlere } \\
\text { Etkisi Ölçeği }\end{array}$}} & Kadın & 235 & 3,60 & 1,068 & \multirow{2}{*}{1,916} & \multirow{2}{*}{0,056} \\
\hline & & Erkek & 229 & 3,41 & 0,979 & & \\
\hline
\end{tabular}

$\mathrm{P}<0,05 ; \mathrm{P}<0,01$

Cinsiyet değişkenine göre öğrencilerin kitap okuma tutumları analiz edildiğinde her üç faktörde de kadın öğrenciler lehine gruplar arasında anlamlı düzeyde farklılık olduğu $(\mathrm{t}=2,453, \mathrm{P}<0,05 ; \mathrm{t}=3,648$, $\mathrm{P}<0,01 ; \mathrm{t}=2,608, \mathrm{P}<0,01)$ görülmektedir. Kişisel ve toplumsal gelişime 
292 | A. KOÇ / Öğrencilerin Kitap Okuma Tutumları ile Kitap Okumanın DKAB Öğretim Programındaki Değerlere Etkisi Arasındaki İlişkinin İncelenmesi

katkı faktörünü kadın öğrenciler $\bar{X}=3,76$ puanla değerlendirirlerken, erkek öğrenciler $\bar{X}=3,57$ puanla değerlendirmişlerdir. Kitap okumaya ilgi duyma ve sevme faktörünü kadın öğrenciler $\bar{X}=3,30$ puanla değerlendirirlerken, erkek öğrenciler $\overline{\mathrm{X}}=3,02$ puanla değerlendirmişlerdir. Kitap okumayı önemli ve değerli bulma faktörünü kadın öğrenciler $\overline{\mathrm{X}}=3,16$ puanla değerlendirirlerken, erkek öğrenciler $\overline{\mathrm{X}}=2,90$ puanla değerlendirmişlerdir. Buna göre, kadın öğrencilerin kitap okuma tutumlarının erkek öğrencilere göre daha yüksek düzeyde olduğu söylenebilir. Cinsiyet değişkenine göre öğrencilerin kitap okumanın değerlere etkisine yönelik görüşleri analiz edildiğinde gruplar arasında anlamlı düzeyde bir farklılık olmadığı görülmektedir. Her iki grubun da bu konudaki görüşleri $(\bar{X}=3,60, \bar{X}=3,41)$ yüksek düzeydedir.

Literatüre bakıldığında genel olarak benzer sonuçlar görülmektedir. Ortaokul, lise ve üniversite öğrencilerine yönelik farklı zamanlarda yapılan çalışmalarda, kadın öğrencilerin kitap okuma tutum, beceri ve alışkanlıklarının erkek öğrencilere oranla daha olumlu olduğu ifade edilmektedir (Demir, 2016, 55; Şahin, 2019, 402; Tonka, 2020, 47; Türegün - Kaya, 2019, 29). Lise öğrencilerine yönelik yapılan bir araştırmada da kız öğrencilerin erkek öğrencilere kıyasla daha çok kitap okudukları, kitapçıya daha sık gittikleri, öğretmenleri ve arkadaşları ile daha çok kitap alış verişi yaptıkları, kitaplar hakkında daha sık konuştukları ve okullarında kütüphane oluşturulması için daha çok gayret gösterdikleri sonucuna varılmıştır (Tüzer, 2016, 72).

3.3 Okul Türü Değişkenine Göre Öğrencilerin Kitap Okuma Tutumları ve Kitap Okumanın Değerlere Etkisine Yönelik Görüssleri

Okul türlerine göre öğrencilerin kitap okuma tutumlarını ve kitap okumanın değerlere etkisine yönelik görüşlerini gösteren veriler Tablo 4 'te sunulmuştur: 
A. KOÇ / Investigation of the Relationship between Attitudes of Students' Reading Book and the Effect of Reading Books on the Values in the RCMK Curriculum I 293

Tablo 4. Okul Türü Değişkenine Göre Öğrencilerin Kitap Okuma Tutumları ve Kitap Okumanın Değerlere Etkisine Yönelik Görüşleri

\begin{tabular}{|c|c|c|c|c|c|c|c|}
\hline \multirow{2}{*}{ Faktör } & \multicolumn{2}{|c|}{ Levene } & \multicolumn{2}{|c|}{ Anova } & \multicolumn{2}{|c|}{ Brown-Forsythe } & \multirow{2}{*}{$\begin{array}{c}\text { Farklılık Olan } \\
\text { Gruplar }\end{array}$} \\
\hline & İstatistik & $\mathrm{P}$ & $\mathrm{F}$ & $\mathrm{P}$ & Statistic $^{a}$ & $\mathrm{P}$ & \\
\hline $\begin{array}{l}\text { Kişisel/ } \\
\text { Toplumsal } \\
\text { Gelişime } \\
\text { Katkı }\end{array}$ & 2,977 & $0,007^{* *}$ & - & - & 5,733 & $0,000^{* *}$ & $\begin{array}{l}\mathrm{AL}, \dot{\mathrm{IK}}, \mathrm{K}> \\
\mathrm{RO}, \mathrm{O} \mathrm{O}, \mathrm{L}, \\
\mathrm{ML}\end{array}$ \\
\hline $\begin{array}{ll}\text { İlgi } & \text { ve } \\
\text { Sevmek } & \\
\end{array}$ & 2,793 & $0,011^{*}$ & - & - & 3,328 & $0,003^{* *}$ & $\begin{array}{l}\dot{\mathrm{IK}}>\mathrm{RO}, \mathrm{ÖO}, \\
\mathrm{L}, \mathrm{ML}\end{array}$ \\
\hline $\begin{array}{l}\text { Önemli- } \\
\text { Değerli } \\
\text { Bulma }\end{array}$ & 0,838 & 0,541 & 4,314 & $0,000^{* *}$ & - & - & $\begin{array}{l}\text { AL, İK, K > } \\
\text { RO, L, ML }\end{array}$ \\
\hline $\begin{array}{l}\text { Kitap } \\
\text { Okumanın } \\
\text { Değerlere } \\
\text { Etkisi Ölçeği }\end{array}$ & 2,863 & $0,010^{*}$ & - & - & 6,522 & $0,000^{* *}$ & $\begin{array}{l}\mathrm{AL}, \mathrm{IK}, \mathrm{K}> \\
\mathrm{RO}, \mathrm{ÖO}, \mathrm{L}, \\
\mathrm{ML}\end{array}$ \\
\hline
\end{tabular}

$\mathrm{P}<0,05 ; \mathrm{P}<0,01$

RO: Resmi Ortaokul; ÖO: Özel Ortaokul; L: Lise; AL: Anadolu Lisesi; ML: Meslek Lisesi; İK: İlahiyat Koleji/Lisesi; K: Kolej

Öğrencilerin okudukları okul türlerine göre kitap okuma tutumlarının değişip değişmediğini belirlemek için önce Levene testi uygulanmış, grupların ilk iki faktörde homojen dağılmadığı, üçüncü faktörde ise homojen dağıldığı görülmüştür. Homojen dağılmayan birinci faktöre Brown-Forsythe testi uygulanmış ve gruplar arasında anlamlı bir farklılık olduğu (Statistic $=5,733, \mathrm{P}<0,01$ ) tespit edilmiştir. Farklılığın hangi gruplar arasında olduğunu belirlemek için yapılan LSD testi sonuçlarına göre Anadolu Lisesi (AL), İlahiyat Koleji/Lisesi (İK) ve Kolej (K) öğrencilerinin diğer okul öğrencilerinden anlamlı düzeyde daha yüksek puan verdikleri tespit edilmiştir. Kişisel ve toplumsal gelişime katkı faktörüne AL öğrencileri $\bar{X}=3,96$ puan; İK öğrencileri $\overline{\mathrm{X}}=3,84$ puan ve $\mathrm{K}$ öğrencileri $\bar{X}=3,86$ puan vermişlerdir. $\mathrm{Bu}$ faktöre Resmi Ortaokul (RO) öğrencileri $\bar{X}=3,55$ puan; Özel Ortaokul (ÖO) öğrencileri $\bar{X}=3,30$ puan; Lise (L) öğrencileri $\bar{X}=3,51$ puan ve Meslek Lisesi (ML) öğrencileri $\bar{X}=3,41$ puan vermişlerdir. Bu sonuçlara göre $A L$, İK ve $K$ okullarındaki öğrencilerin kitap okumanın kişisel ve toplumsal 
294 | A. KOÇ / Öğrencilerin Kitap Okuma Tutumları ile Kitap Okumanın DKAB Öğretim Programındaki Değerlere Etkisi Arasındaki İlişkinin İncelenmesi

gelişimlerine katkı sağladığını daha fazla düşündükleri söylenebilir. Bunun sebebi olarak bu okulların akademik eğitime daha fazla ağırlık vermeleri olabilir.

Kitap okuma tutum ölçeğinin homojen dağılmayan ikinci faktörüne Brown-Forsythe testi uygulanmış ve gruplar arasında anlamlı bir farklılık olduğu (Statistic $\left.{ }^{a}=3,328, P<0,01\right)$ tespit edilmiştir. Farklılığın hangi gruplar arasında olduğunu belirlemek için yapılan LSD testi sonuçlarına göre ilgi ve sevmek faktöründe İK öğrencilerinin $\mathrm{RO}, \mathrm{ÖO}, \mathrm{L}$ ve ML öğrencilerinden daha yüksek puan verdikleri tespit edilmiştir. $\mathrm{Bu}$ faktöre İK öğrencileri $\bar{X}=3,39$ puan verirlerken, $R O$ öğrencileri $\bar{X}=2,98$ puan, ÖO öğrencileri $\bar{X}=2,94$ puan, $L$ öğrencileri $\bar{X}=3,07$ puan ve ML öğrencileri $\overline{\mathrm{X}}=3,06$ puan vermişlerdir. $\mathrm{Bu}$ sonuçlara göre $\dot{\mathrm{I} K}$ öğrencilerinin kitap okumaya yönelik ilgi ve sevgilerinin diğer okullardan daha yüksek olduğu söylenebilir. Bunun sebebi olarak öğrencilerin İlahiyat koleji/lisesi içindeki etkinlikler ve kütüphane imkânları sayesinde kitaba daha kolay ulaşmaları söylenebilir (Kulu, 2017, 4). Farklı lise türlerinde okuyan öğrencilere yönelik yapılan bir araştırmada da benzer bir sonuçtan bahsedilerek, İmam Hatip Lisesinde öğrenim gören öğrencilerin diğer okul öğrencilerinden daha fazla kitap okumayı sevdikleri, alışkanlık haline getirdikleri ve daha istekli ve yararlı gördükleri görülmüştür. Bu durumun okulların kütüphane ve içeriğinde kitap sayısı ile birlikte erişiminin kolay olması durumu ile bağdaştırılabileceği ifade edilmektedir (Yıldırım - Ceylan, 2018, 743).

Kitap okuma tutum ölçeğinin homojen dağılan üçüncü faktörüne Anova testi uygulanmış ve gruplar arasında anlamlı bir farklılık olduğu $(\mathrm{F}=4,314 ; \mathrm{P}<0,01)$ tespit edilmiştir. Farklılığın hangi gruplar arasında olduğunu belirlemek için yapılan LSD testi sonuçlarına göre AL, İK ve K öğrencilerinin $R O, L$ ve $M L$ öğrencilerinden daha yüksek puan verdikleri görülmüştür. $\mathrm{Bu}$ faktöre $\mathrm{AL}$ öğrencileri $\overline{\mathrm{X}}=3,31$ puan, İK öğrencileri $\bar{X}=3,17$ puan ve $K$ öğrencileri $\bar{X}=3,28$ puan verirlerken, $R O$ öğrencileri $\bar{X}=2,62$ puan, $L$ öğrencileri $\bar{X}=2,89$ puan ve $M L$ öğrencileri $\bar{X}=2,85$ puan vermişlerdir. Bu sonuçlara göre $A L$, İ ve $K$ öğrencilerinin kitap okumaya verdikleri değer ve önemin diğer okullardan daha yüksek olduğu söylenebilir. Bunun sebebi olarak bu okulların akademik eğitime daha fazla ağırlık vermeleri olabilir. Kitap okuma tutum ve becerileriyle akademik başarı arasındaki ilişkiyi inceleyen araştırmalarda benzer bulgular yer almaktadır. Okunan kitap sayısıyla 
A. KOÇ / Investigation of the Relationship between Attitudes of Students' Reading Book and the Effect of Reading Books on the Values in the RCMK Curriculum I 295 öğrencilerin akademik başarıları arasında pozitif yönde bir ilişki olduğu (Güney vd., 2014, 157), öğrencilerin okuduklarını anlama becerileri, okuma motivasyonları ve okumayı alışkanlık hâline getirmelerinin akademik başarılarında büyük bir etkiye (\%61) sahip olduğu ifade edilmektedir (Yıldız, 2013, 1473).

Kitap okumanın değerlere etkisine yönelik öğrencilerin görüşlerini analiz etmek için önce Levene testi uygulanmış, grupların homojen dağılmadığ1 görülmüştür. Bunun üzerine Brown-Forsythe testi uygulanmış ve gruplar arasında anlamlı bir farklılık olduğu (Statistic $\mathrm{c}^{\mathrm{a}}=6,522, \mathrm{P}<0,01$ ) tespit edilmiştir. Farklılı̆̆ın hangi gruplar arasında olduğunu belirlemek için yapılan LSD testi sonuçlarına göre $\mathrm{AL}$, İK ve K öğrencilerinin diğer okul öğrencilerinden anlamlı düzeyde daha yüksek puan verdikleri tespit edilmiştir. Kitap okumanın değerlere etkisi ölçeğine $A L$ öğrencileri $\bar{X}=3,69$ puan; İK öğrencileri $\bar{X}=3,72$ puan ve $K$ öğrencileri $\bar{X}=3,94$ puan vermişlerdir. Ölçeğe RO öğrencileri $\bar{X}=3,37$ puan; ÖO öğrencileri $\bar{X}=2,96$ puan; $L$ öğrencileri $\bar{X}=3,16$ puan ve $M L$ öğrencileri $\bar{X}=3,38$ puan vermişlerdir. Bu sonuçlara göre $A L$, İK ve $K$ okullarındaki öğrencilerin kitap okumanın değerleri etkilediğini daha fazla düşündükleri söylenebilir.

3.4 Sınıf Düzeyi Değişkenine Göre Öğrencilerin Kitap Okuma Tutumları ve Kitap Okumanın Değerlere Etkisine Yönelik Görüssleri

Öğrencilerin sınıf düzeylerine göre kitap okuma tutumlarını ve kitap okumanın değerlere etkisine yönelik görüşlerini gösteren veriler Tablo 5'te sunulmuştur:

Tablo 5. Sınıf Düzeylerine Göre Öğrencilerin Kitap Okuma Tutumları ve Kitap Okumanın Değerlere Etkisine Yönelik Görüşleri

\begin{tabular}{|c|c|c|c|c|c|c|c|}
\hline Ölçek & Faktör & Sinif & $\mathrm{N}$ & $\overline{\mathrm{X}}$ & SD & $\mathrm{t}$ & $\mathrm{P}$ \\
\hline \multirow{6}{*}{$\begin{array}{l}\text { Kitap } \\
\text { Okuma } \\
\text { Tutum } \\
\text { Ölçeği }\end{array}$} & \multirow{2}{*}{$\begin{array}{l}\text { Kişisel/Toplumsal } \\
\text { Gelişime Katk1 }\end{array}$} & Ortaokul & 202 & 3,69 & 0,731 & \multirow{2}{*}{0,626} & \multirow{2}{*}{0,532} \\
\hline & & Lise & 262 & 3,64 & 0,889 & & \\
\hline & \multirow{2}{*}{ İlgi ve Sevmek } & Ortaokul & 202 & 3,16 & 0,833 & \multirow{2}{*}{0,001} & \multirow{2}{*}{0,999} \\
\hline & & Lise & 262 & 3,16 & 0,852 & & \\
\hline & \multirow{2}{*}{$\begin{array}{l}\text { Önemli-Değerli } \\
\text { Bulma }\end{array}$} & Ortaokul & 202 & 2,95 & 1,059 & \multirow{2}{*}{$-1,435$} & \multirow{2}{*}{0,152} \\
\hline & & Lise & 262 & 3,09 & 1,058 & & \\
\hline \multirow{2}{*}{\multicolumn{2}{|c|}{$\begin{array}{c}\text { Kitap Okumanın Değerlere } \\
\text { Etkisi Ölçeği }\end{array}$}} & Ortaokul & 202 & 3,62 & 0,897 & \multirow{2}{*}{2,123} & \multirow{2}{*}{$0,034^{*}$} \\
\hline & & Lise & 262 & 3,42 & 1,113 & & \\
\hline
\end{tabular}

$\mathrm{P}<0,05$ 
296 | A. KOÇ / Öğrencilerin Kitap Okuma Tutumları ile Kitap Okumanın DKAB Öğretim Programındaki Değerlere Etkisi Arasındaki İlişkinin İncelenmesi

Sınıf düzeyi değişkenine göre öğrencilerin kitap okuma tutumları analiz edildiğinde ölçeğin hiçbir faktöründe gruplar arasında anlamlı düzeyde bir farklılık olmadığı tespit edilmiştir. Buna göre öğrencilerin kitap okuma tutumları ortaokul ve lise düzeyinde okuma durumlarına göre değişmemektedir. Tüm grupların kitap okumanın kişisel ve toplumsal gelişime katkısına yönelik görüşleri yüksek düzeyde $(\bar{X}=3,69$, $\bar{X}=3,64)$; kitap okumaya karşı ilgi, sevgi $(\bar{X}=3,16, \bar{X}=3,16)$; önemli ve değerli bulma ile ilgili $(\bar{X}=2,95, \bar{X}=3,09)$ görüşleri ise orta düzeydedir. Sınıf düzeyi değişkenine göre öğrencilerin kitap okumanın değerlere etkisine yönelik görüşlerini analiz edildiğinde ortaokul öğrencileri lehine anlamlı düzeyde bir farklılık olduğu $(\mathrm{t}=2,123 ; \quad \mathrm{P}<0,05)$ görülmektedir. Ortaokul öğrencileri ölçeğe $\bar{X}=3,62$ puan verirlerken lise öğrencileri $\overline{\mathrm{X}}=3,42$ puan vermişlerdir. $\mathrm{Bu}$ sonuca göre ortaokul öğrencilerinin kitap okumanın değerlere etkisinin olduğunu daha çok düşündükleri söylenebilir. Bunun sebebi, ergenlik dönemindeki ortaokul öğrencilerinin kişilik ve karakter gelişim dönemlerinde olmasına bağlı olarak bunu daha fazla hissetmeleri ile açılanabilir.

Literatürde öğrencilerin sınıf ve yaş seviyelerine göre kitap okuma becerileri ve tutumları ile bu araştırma ile örtüşen ve ayrılan sonuçlar bulunmaktadır. Ortaokul ve lise öğrencileriyle yapılan iki ayrı araştırmada öğrencilerin sınıf düzeyi yükseldikçe daha fazla okumaya yöneldikleri, bunun sebebi olarak başarının yükseltilmesi ve sinav heyecanı ile mücadele edilmesi olarak açıklanmıştır (Dilbaz, 2019, 43; Yıldırım - Ceylan, 2018, 744). Ortaokul öğrencilerinin kitap okuma alışkanlıklarının incelendiği bir araştırmada sınıf değişkeni açısından anlamlı bir farklılık olmadığ ifade edilmektedir (Tonka, 2020, 55).

\subsection{Evlerinde Çalışma Odasının Var Olması Durumuna Göre Öğrencilerin Kitap Okuma Tutumları ve Kitap Okumanın Değerlere Etkisine Yönelik Görüşleri \\ Öğrencilerin evlerinde kendilerine ait çalışma odasının var olması durumuna göre kitap okuma tutumlarını ve kitap okumanın değerlere etkisine yönelik görüşlerini gösteren veriler Tablo 6' da sunulmuştur:}


A. KOÇ / Investigation of the Relationship between Attitudes of Students' Reading Book and the Effect of Reading Books on the Values in the RCMK Curriculum I 297

Tablo 6. Çalışma Odasının Var Olması Durumuna Göre Öğrencilerin Kitap Okuma Tutumları ve Kitap Okumanın Değerlere Etkisine Yönelik Görüşleri

\begin{tabular}{|c|c|c|c|c|c|c|c|}
\hline Ölçek & Faktör & $\begin{array}{l}\text { Çalışma } \\
\text { Odası }\end{array}$ & $\mathrm{N}$ & $\overline{\mathrm{X}}$ & SD & $t$ & $\mathrm{P}$ \\
\hline \multirow{6}{*}{$\begin{array}{l}\text { Kitap } \\
\text { Okuma } \\
\text { Tutum } \\
\text { Ölçeği }\end{array}$} & \multirow{2}{*}{$\begin{array}{l}\text { Kişisel/Toplumsal } \\
\text { Gelişime Katkı }\end{array}$} & Var & 365 & 3,72 & 0,797 & \multirow{2}{*}{2,764} & \multirow{2}{*}{$0,006^{* *}$} \\
\hline & & Yok & 99 & 3,46 & 0,891 & & \\
\hline & \multirow{2}{*}{ İlgi ve Sevmek } & Var & 365 & 3,19 & 0,856 & \multirow{2}{*}{1,347} & \multirow{2}{*}{0,179} \\
\hline & & Yok & 99 & 3,06 & 0,790 & & \\
\hline & Önemli-Değerli & Var & 365 & 3,09 & 1,072 & \multirow{2}{*}{2,140} & \multirow{2}{*}{$0,033^{*}$} \\
\hline & Bulma & Yok & 99 & 2,83 & 0,992 & & \\
\hline \multirow{2}{*}{\multicolumn{2}{|c|}{$\begin{array}{c}\text { Kitap Okumanın Değerlere } \\
\text { Etkisi Ölçeği }\end{array}$}} & Var & 365 & 3,56 & 1,022 & \multirow{2}{*}{2,035} & \multirow{2}{*}{$0,042^{*}$} \\
\hline & & Yok & 99 & 3,32 & 0,035 & & \\
\hline
\end{tabular}

$\mathrm{P}<0,05 ; \mathrm{P}<0,01$

Öğrencilerin evlerinde kendilerine ait çalışma odasının var olması durumuna göre kitap okuma tutumları analiz edildiğinde ilgi ve sevmek faktörü hariç diğer iki faktörde gruplar arasında anlamlı düzeyde farklılık olduğu $(\mathrm{t}=2,764, \mathrm{P}<0,01 ; \mathrm{t}=2,140, \mathrm{P}<0,05)$ görülmektedir. Kişisel ve toplumsal gelişime katkı faktöründe çalışma odası olan öğrenciler $\overline{\mathrm{X}}=3,72$ puanla değerlendirirlerken, çalışma odası olmayan öğrenciler $\overline{\mathrm{X}}=3,46$ puanla değerlendirmişlerdir. Kitap okumayı önemli ve değerli bulma faktöründe çalışma odası olan öğrenciler $\bar{X}=3,09$ puanla değerlendirirlerken, çalışma odası olmayan öğrenciler $\bar{X}=2,83$ puanla değerlendirmişlerdir. Buna göre, evlerinde kendilerine ait çalışma odası olan öğrencilerin kitap okumanın kişisel ve toplumsal gelişime katkı sağladığı ile kitap okumayı önemli ve değerli bulmaya yönelik görüşleri, çalışma odası olmayan öğrencilere göre daha yüksek düzeydedir.

Çalışma odasının var olması durumuna göre öğrencilerin kitap okumanın değerlere etkisine yönelik görüşleri analiz edildiğinde çalışma odası olanlar lehine anlamlı düzeyde bir farklılık olduğu $(t=2,035, P<0,05)$ görülmektedir. Çalışma odası olan öğrenciler ölçeği, $\overline{\mathrm{X}}=3,56$ puanla yüksek düzeyde değerlendirirlerken, çalışma odası olmayan öğrenciler $\bar{X}=3,32$ puanla orta düzeyde değerlendirmişlerdir. Buna göre, evlerinde kendilerine ait çalışma odası olan öğrencilerin kitap okumanın değerleri etkilediğine yönelik görüşleri, çalışma odası olmayan öğrencilere göre daha yüksek düzeydedir. Bu iki sonucun 
298 | A. KOÇ / Öğrencilerin Kitap Okuma Tutumları ile Kitap Okumanın DKAB Öğretim Programındaki Değerlere Etkisi Arasındaki İlişkinin İncelenmesi

sebebi, evlerinde çalışma odası olan öğrencilerin kitap okuma ortamına daha uygun şartlarda yaşamaları ile açıklanabilir.

Çocuğun özel odasının olması ile ailenin gelir durumu arasındaki yakın irtibat göz önünde bulundurularak literatürdeki hem çocuğun özel odasının hem de ailenin gelir durumunun kitap okumaya etkisi ile ilgili araştırmalar incelenmiştir. Buna göre gelir durumunun kitap okuma alışkanlıklarını etkilediği ve genel anlamda orta düzeydeki sosyo-ekonomik çevrede bulunan öğrencilerin kitap okuma tutum ve alışkanlıklarının daha yüksek olduğu ifade edilmektedir (Balcı, 2009, 291; Şahin, 2012, 382). Başka bir araştırmada, çalışma odası olan öğrencilerin daha çok kitap, dergi ve gazete okudukları tespit edilmiştir (Tüzer, 2016, 72). Ortaokul öğrencileriyle yapılan bir araştırmada da öğrencilerin \%46'sının evde kitap okumak için uygun ortam bulamadığ1 ve kitap okuma tutumunun bu durumdan olumsuz etkilendiği ifade edilmektedir (Calp, 2018, 908).

3.6 Evlerinde Kitaplık/Kitap Köşesi Olması Durumuna Göre Öğrencilerin Kitap Okuma Tutumları ve Kitap Okumanın Değerlere Etkisine Yönelik Görüşleri

Öğrencilerin evlerinde kitaplık/kitap köşesi olması durumuna göre kitap okuma tutumlarını ve kitap okumanın değerlere etkisine yönelik görüşlerini gösteren veriler Tablo 7'de sunulmuştur:

Tablo 7. Kitaplık/Kitap Köşesi Olması Durumuna Göre Öğrencilerin Kitap Okuma Tutumları ve Kitap Okumanın Değerlere Etkisine Yönelik Görüşleri

\begin{tabular}{|c|c|c|c|c|c|c|c|}
\hline Ölçek & Faktör & $\begin{array}{l}\text { Evinde } \\
\text { Kitaplık }\end{array}$ & $\mathrm{N}$ & $\overline{\mathrm{X}}$ & SD & $\mathrm{t}$ & $\mathrm{P}$ \\
\hline \multirow{6}{*}{$\begin{array}{l}\text { Kitap } \\
\text { Okuma } \\
\text { Tutum } \\
\text { Ölçeği }\end{array}$} & Kişisel/Toplumsal & Var & 339 & 3,79 & 0,765 & \multirow{2}{*}{5,836} & \multirow{2}{*}{$0,000^{* *}$} \\
\hline & Gelişime Katk1 & Yok & 125 & 3,31 & 0,873 & & \\
\hline & \multirow{2}{*}{ İlgi ve Sevmek } & Var & 339 & 3,27 & 0,829 & \multirow{2}{*}{4,683} & \multirow{2}{*}{$0,000^{* *}$} \\
\hline & & Yok & 125 & 2,87 & 0,812 & & \\
\hline & Önemli-Değerli & Var & 339 & 3,09 & 1,073 & \multirow{2}{*}{1,908} & \multirow{2}{*}{0,057} \\
\hline & Bulma & Yok & 125 & 2,88 & 1,011 & & \\
\hline \multirow{2}{*}{\multicolumn{2}{|c|}{$\begin{array}{c}\text { Kitap Okumanın Değerlere } \\
\text { Etkisi Ölçeği }\end{array}$}} & Var & 339 & 3,63 & 0,986 & \multirow{2}{*}{4,430} & \multirow{2}{*}{$0,000^{* *}$} \\
\hline & & Yok & 125 & 3,16 & 1,066 & & \\
\hline
\end{tabular}

$\mathrm{P}<0,01$ 
A. KOÇ / Investigation of the Relationship between Attitudes of Students' Reading Book and the Effect of Reading Books on the Values in the RCMK Curriculum। 299

Öğrencilerin evlerinde kitaplık/kitap köşesi olması durumuna göre kitap okuma tutumları analiz edildiğinde önemli ve değerli bulma faktörü hariç diğer iki faktörde gruplar arasında anlamlı düzeyde farklılık olduğu ( $\mathrm{t}=5,836, \mathrm{P}<0,01 ; \mathrm{t}=4,683, \mathrm{P}<0,01)$ görülmektedir. Kişisel ve toplumsal gelişime katkı faktöründe kitaplık/kitap köşesi olan öğrenciler $\overline{\mathrm{X}}=3,79$ puanla değerlendirirlerken, kitaplık/kitap köşesi olmayan öğrenciler $\bar{X}=3,31$ puanla değerlendirmişlerdir. Kitap okumaya ilgi ve sevgi duyma bulma faktöründe kitaplık/kitap köşesi olan öğrenciler $\overline{\mathrm{X}}=3,27$ puanla değerlendirirlerken, kitaplı/kitap köşesi olmayan öğrenciler $\overline{\mathrm{X}}=2,87$ puanla değerlendirmişlerdir. Buna göre, evlerinde kendilerine ait kitaplık/kitap köşesi olan öğrencilerin, kitap okumanın kişisel ve toplumsal gelişime katkı sağladığına yönelik görüşleri ile kitap okumaya duydukları ilgi ve sevgi, kitaplık/kitap köşesi olmayan öğrencilere göre daha yüksek düzeydedir.

Kitaplık/kitap köşesi olması durumuna göre öğrencilerin kitap okumanın değerlere etkisine yönelik görüşleri analiz edildiğinde kitaplık/kitap köşesi olanlar lehine anlamlı düzeyde bir farklılık olduğu $(\mathrm{t}=4,430, \mathrm{P}<0,01)$ görülmektedir. Kitaplık/kitap köşesi olan öğrenciler ölçeği, $\bar{X}=3,63$ puanla yüksek düzeyde değerlendirirlerken, kitaplık/kitap köşesi olmayan öğrenciler $\overline{\mathrm{X}}=3,16$ puanla orta düzeyde değerlendirmişlerdir. Buna göre, evlerinde kendilerine ait kitaplık/kitap köşesi olan öğrencilerin kitap okumanın değerleri etkilediğine yönelik görüşleri kitaplık/kitap köşesi olmayan öğrencilere göre daha yüksek düzeydedir. Bu iki sonucun sebebi, evlerinde kitaplık/kitap köşesi olan öğrencilerin kitaba erişimlerinin daha kolay olması ile açıklanabilir. Çünkü ortaokul öğrencileriyle yapılan bir araştırmada evlerinde kitap köşesi olan öğrencilerin, kitap köşesi olmayan öğrencilere kıyasla daha çok gazete, dergi ve kitap okudukları, kitapçılara daha sık gittikleri ve aile içinde kitaplar hakkında daha çok konuştukları sonucuna ulaşılmıştır (Tüzer, 2016, 72).

\subsection{Yılda Okuduğu Kitap Sayısına Göre Öğrencilerin Kitap Okuma Tutumları ve Kitap Okumanın Değerlere Etkisine Yönelik Görüşleri}

Kitap okuma sayılarına göre öğrencilerin kitap okuma tutumlarını ve kitap okumanın değerlere etkisine yönelik görüşlerini gösteren veriler Tablo 8'de sunulmuştur: 
300 | A. KOÇ / Öğrencilerin Kitap Okuma Tutumları ile Kitap Okumanın DKAB Öğretim Programındaki Değerlere Etkisi Arasındaki İlişkinin İncelenmesi

Tablo 8. Yılda Okudukları Kitap Sayısına Göre Öğrencilerin Kitap Okuma Tutumları ve Kitap Okumanın Değerlere Etkisine Yönelik Görüşleri

\begin{tabular}{|c|c|c|c|c|c|}
\hline \multirow{2}{*}{ Faktör } & \multicolumn{2}{|c|}{ Levene } & \multicolumn{2}{|c|}{ Anova } & \multirow{2}{*}{$\begin{array}{c}\text { Farklılık Olan } \\
\text { Gruplar }\end{array}$} \\
\hline & İstatistik & $\mathrm{P}$ & $\mathrm{F}$ & $\mathrm{P}$ & \\
\hline $\begin{array}{l}\text { Kişisel/ } \\
\text { Toplumsal } \\
\text { Gelişime } \\
\text { Katk1 } \\
\end{array}$ & 0,897 & 0,443 & 30,431 & $0,000^{* *}$ & $\begin{array}{l}\text { Hiç }<\text { Az, orta, çok } \\
\text { Az }<\text { Orta, çok }\end{array}$ \\
\hline $\begin{array}{l}\text { İlgi ve } \\
\text { Sevmek }\end{array}$ & 2,384 & 0,069 & 40,858 & $0,000^{* *}$ & $\begin{array}{l}\text { Hiç }<\text { Az, orta, çok } \\
\mathrm{Az}<\text { Orta, çok }\end{array}$ \\
\hline $\begin{array}{l}\text { Önemli- } \\
\text { Değerli } \\
\text { Bulma }\end{array}$ & 2,108 & 0,098 & 16,871 & $0,000^{* *}$ & $\begin{array}{l}\text { Hiç }<\mathrm{Az} \text {, orta, çok } \\
\mathrm{Az}<\text { Orta, çok }\end{array}$ \\
\hline $\begin{array}{l}\text { Kitap } \\
\text { Okumanın } \\
\text { Değerlere } \\
\text { Etkisi Ölçeği }\end{array}$ & 2,613 & 0,051 & 13,840 & $0,000^{* *}$ & $\begin{array}{l}\text { Hiç }<\text { Az, orta, çok } \\
\mathrm{Az}<\text { Orta, çok }\end{array}$ \\
\hline
\end{tabular}

Hiç: Hiç Okumayan; Az: 1-5 Kitap Okuyan; Orta: 5-19 Kitap Okuyan; Çok: 20+ Kitap Okuyan

Öğrencilerin yılda okudukları kitap sayılarına göre kitap okuma tutumlarının değişip değişmediğini belirlemek için önce Levene testi uygulanmış, grupların tüm faktörlerde homojen dağıldığı görülmüştür. Ardından yapılan Anova testi sonuçlarına göre tüm faktörlerde gruplar arasında anlamlı düzeyde ( $\mathrm{F}=30,431, \mathrm{P}<0,01 ; \mathrm{F}=40,858, \mathrm{P}<0,01 ; \mathrm{F}=16,871$, $\mathrm{P}<0,01)$ farklılık olduğu tespit edilmiştir. Farklılığın hangi gruplar arasında olduğunu belirlemek için yapılan LSD testi sonuçlarına göre yılda hiç kitap okumayan veya az kitap okuyan öğrencilerin orta ve çok düzeyde kitap okuyan öğrencilerden daha düşük bir kitap okuma tutumuna sahip oldukları tespit edilmiştir. Kişisel ve toplumsal gelişime katk1 faktörünü hiç okumayan öğrenciler $\bar{X}=2,91$ puanla ve az kitap okuyan öğrenciler $\overline{\mathrm{X}}=3,16$ puanla değerlendirmişlerdir. Aynı faktörü orta düzey kitap okuyanlar $\bar{X}=3,84$ puanla ve çok okuyan öğrenciler ise $\bar{X}=3,99$ puanla değerlendirmişlerdir. İlgi ve sevmek faktörünü hiç okumayan öğrenciler $\overline{\mathrm{X}}=2,39$ puanla ve az kitap okuyan öğrenciler $\overline{\mathrm{X}}=3,14$ puanla değerlendirmişlerdir. Aynı faktörü orta düzey kitap okuyanlar $\bar{X}=3,51$ puanla ve çok okuyan öğrenciler ise $\bar{X}=3,70$ puanla 
A. KOÇ / Investigation of the Relationship between Attitudes of Students' Reading Book and the Effect of Reading Books on the Values in the RCMK Curriculum I 301 değerlendirmişlerdir. Önemli/değerli bulma faktörünü hiç okumayan öğrenciler $\overline{\mathrm{X}}=2,52$ puanla ve az kitap okuyan öğrenciler $\overline{\mathrm{X}}=2,92$ puanla değerlendirmişlerdir. Aynı faktörü orta düzey kitap okuyanlar $\bar{X}=3,42$ puanla ve çok okuyan öğrenciler ise $\bar{X}=3,58$ puanla değerlendirmişlerdir. Buna göre her üç faktörde de hiç okumayan ve az okuyan öğrencilerle orta düzey ve çok okuyan öğrenciler arasında anlamlı farklılık olduğu görülmektedir. Bu sonuç doğal bir sonuç olarak kabul edilebilir, çünkü yılda hiç kitap okumayan veya az kitap okuyan öğrenciler için kitap okumanın bir beceri ve alışkanlık haline geldiği söylenemez. Yılda hiç kitap okumayan ve az kitap okuyan öğrencilerin, araştırmaya katılan öğrencilerin çoğunluğunu oluşturması $(\mathrm{N}=312, \% 67,2)$, kitap okumanın eğitimcilerin, araştırmacıların ve ebeveynlerin üzerine eğilmesi gereken bir konu olduğunu göstermektedir. Ortaokul öğrencileriyle yapılan bir araştırmada ise farklı bir sonuç ortaya koyularak, öğrencilerin $\% 20,7^{\prime} \operatorname{sinin}$ hiç okumayan ve az okuyan grubunda olduğu; \%56,8'nin orta düzeyde bir okuyucu olduğu ve \%22,5'unun ise çok okuyan grubunda olduğu ve önceki araştırmalara kıyasla bu sonucun sevindirici olduğu ifade edilmektedir (Deniz, 2015, 55).

Öğrencilerin yılda okudukları kitap sayılarına göre kitap okumanın değerlere etkisine yönelik görüşlerini analiz etmek için yapılan Levene testinde grupların homojen dağıldığı görülmüştür. Ardinda yapilan Anova testinde gruplar arasinda anlamlı farklılık olduğu $(\mathrm{F}=13,840, \mathrm{P}<0,01)$ tespit edilmiştir. Farklılığın hangi gruplar arasında olduğunu belirlemek için yapılan LSD testi sonuçlarına göre yılda hiç kitap okumayan veya az kitap okuyan öğrencilerin, orta ve çok düzeyde kitap okuyan öğrencilerden daha düşük değerlendirdikleri tespit edilmiştir. Kitap okumanın değerlere etkisine yönelik yapılan ölçeği, hiç okumayan öğrenciler $\bar{X}=2,85$ puanla ve az kitap okuyan öğrenciler $\bar{X}=3,19$ puanla değerlendirmişlerdir. Aynı faktörü orta düzey kitap okuyanlar $\bar{X}=3,67$ puanla ve çok okuyan öğrenciler ise $\bar{X}=3,84$ puanla değerlendirmişlerdir. Bu sonuçlara göre daha fazla kitap okuyan öğrencilerin değerlerin kitaplardan etkilendiğine yönelik görüşlerinin daha yüksek olduğu söylenebilir. 
302 | A. KOÇ / Öğrencilerin Kitap Okuma Tutumları ile Kitap Okumanın DKAB Öğretim Programındaki Değerlere Etkisi Arasındaki İlişkinin İncelenmesi

\subsection{Okul Kütüphanesinden Kitap Alma Durumuna Göre} Öğrencilerin Kitap Okuma Tutumları ve Kitap Okumanın Değerlere Etkisine Yönelik Görüşleri

Öğrencilerin okul kütüphanesinden kitap alma durumlarına göre kitap okuma tutumlarını ve kitap okumanın değerlere etkisine yönelik görüşlerini gösteren veriler Tablo 9' da sunulmuştur:

Tablo 9. Okul Kütüphanesinden Kitap Alma Durumlarına Öğrencilerin

Kitap Okuma Tutumları ve Kitap Okumanın Değerlere Etkisine Yönelik

Görüşleri

\begin{tabular}{|c|c|c|c|c|c|c|c|}
\hline Ölçek & Faktör & $\begin{array}{l}\text { Okul } \\
\text { Kütüphanesinden } \\
\text { Kitap Alma }\end{array}$ & $\mathrm{N}$ & $\overline{\mathrm{X}}$ & SD & $\mathrm{t}$ & $\mathrm{P}$ \\
\hline \multirow{6}{*}{$\begin{array}{l}\text { Kitap } \\
\text { Okuma } \\
\text { Tutum } \\
\text { Ölçeği }\end{array}$} & $\begin{array}{l}\text { Kişisel/ } \\
\text { Toplumsal }\end{array}$ & Evet, aldım. & 291 & 3,75 & 0,769 & \multirow{2}{*}{2,890} & \multirow{2}{*}{$0,004^{* *}$} \\
\hline & Gelişime & Hayır, almadım. & 173 & 3,52 & 0,892 & & \\
\hline & İlgi ve & Evet, aldım. & 291 & 3,30 & 0,818 & \multirow{2}{*}{4,584} & \multirow{2}{*}{$0,000^{* *}$} \\
\hline & Sevmek & Hayır, almadım. & 173 & 2,93 & 0,838 & & \\
\hline & \multirow{2}{*}{$\begin{array}{l}\text { Önemli- } \\
\text { Değerli }\end{array}$} & Evet, aldım. & 291 & 3,10 & 1,067 & \multirow{2}{*}{1,723} & \multirow{2}{*}{0,085} \\
\hline & & Hayır, almadım. & 173 & 2,92 & 1,041 & & \\
\hline \multirow{2}{*}{\multicolumn{2}{|c|}{$\begin{array}{c}\text { Kitap Okumanın } \\
\text { Değerlere Etkisi Ölçeği }\end{array}$}} & Evet, aldım. & 291 & 3,59 & 0,975 & \multirow{2}{*}{2,178} & \multirow{2}{*}{$0,030^{*}$} \\
\hline & & Hayır, almadım. & 173 & 3,37 & 1,102 & & \\
\hline
\end{tabular}

$\mathrm{P}<0,05 ; \mathrm{P}<0,01$

Öğrencilerin okul kütüphanesinden kitap alma durumlarına göre kitap okuma tutumları analiz edildiğinde önemli ve değerli bulma faktörü hariç diğer iki faktörde gruplar arasında anlamlı düzeyde farklılık olduğu $(\mathrm{t}=2,890, \mathrm{P}<0,01 ; \mathrm{t}=4,584 \mathrm{P}<0,01)$ görülmektedir. Kişisel ve toplumsal gelişime katkı faktöründe okul kütüphanesinden kitap alan öğrenciler $\overline{\mathrm{X}}=3,75$ puanla değerlendirirlerken, okul kütüphanesinden kitap almayan öğrenciler $\bar{X}=3,52$ puanla değerlendirmişlerdir. Kitap okumaya ilgi ve sevgi duyma bulma faktöründe okul kütüphanesinden kitap alan öğrenciler $\bar{X}=3,30$ puanla değerlendirirlerken, okul kütüphanesinden kitap almayan öğrenciler $\overline{\mathrm{X}}=2,93$ puanla değerlendirmişlerdir. Okul kütüphanesinden kitap alma durumlarına göre öğrencilerin kitap okumanin değerlere etkisine yönelik görüşleri analiz edildiğinde okul kütüphanesinden kitap alanlar 
A. KOÇ / Investigation of the Relationship between Attitudes of Students' Reading Book and the Effect of Reading Books on the Values in the RCMK Curriculum I 303 lehine anlamlı düzeyde bir farklılık olduğu $(\mathrm{t}=2,178, \quad \mathrm{P}<0,05)$ görülmektedir. Okul kütüphanesinden kitap alan öğrenciler ölçeği, $\bar{X}=3,59$ puanla yüksek düzeyde değerlendirirlerken, okul kütüphanesinden kitap almayan öğrenciler $\bar{X}=3,37$ puanla orta düzeyde değerlendirmişlerdir.

Bu sonuçlara göre, okul kütüphanesinden kitap alan öğrencilerin kitap okumanın değerleri etkilediğine yönelik görüşleri, almayan öğrencilere göre daha yüksek düzeydedir. Bu iki sonucun sebebi, okul kütüphanesinden kitap alan öğrencilerin kitaba erişimlerinin daha kolay olması ile açıklanabilir. Ayrıca şimdiye kadar okul kütüphanesinden kitap almayan öğrencilerin, araştırmaya katılan öğrencilerin yarısına yaklaşması (N=173, \%37,3), kitap okumanın eğitimcilerin, araştırmacıların ve ebeveynlerin üzerine eğilmesi gereken bir konu olduğunu göstermektedir. Çünkü bu sonuç, kitap okuma alışkanlığının en kolay kazandırılabileceği dönem (çocukluk-gençlik), mekân (okul) ve kişi (öğretmen) unsurlarının öğrencilerin yarısına yakını için kullanılmadığını göstermektedir. Ortaokul öğrencileriyle yapılan bir araştırmada benzer bir sonuç ortaya koyularak, öğrencilerin önemli bir k1smının $(\% 41,1)$ okul kütüphanesini kullanmadıkları tespit edilmiştir (Deniz, 2015, 56). Hâlbuki ortaokul öğrencileriyle yapılan iki ayrı araştırmada, okumayı gerçekleştirmek için kaynağa ulaşmada en büyük yardımcılardan birinin okul kitaplıkları olduğu (İşçan vd., 2013, 4), öğretmenlerin okudukları kitapları sınıfta tanıtmalarının, öğrenciler tarafindan olumlu değerlendirildiği ve öğretmenin kitap okuma becerisi bakımından model alındığı sonucuna varılmıştır (Yaman - Süğümlü, 2010, 304).

\subsection{Okul Dişındaki Bir Kütüphaneye Gitme Durumuna Göre Öğrencilerin Kitap Okuma Tutumları ve Kitap Okumanın Değerlere Etkisine Yönelik Görüşleri \\ Öğrencilerin okul dışındaki bir kütüphaneye gitme durumlarına göre kitap okuma tutumlarını ve kitap okumanın değerlere etkisine yönelik görüşlerini gösteren veriler Tablo 10 ' da sunulmuştur:}


304 | A. KOÇ / Öğrencilerin Kitap Okuma Tutumları ile Kitap Okumanın DKAB Öğretim Programındaki Değerlere Etkisi Arasındaki İlişkinin İncelenmesi

Tablo 10. Okul Dışındaki Bir Kütüphaneye Gitme Durumlarına Öğrencilerin Kitap Okuma Tutumları ve Kitap Okumanın Değerlere Etkisine Yönelik Görüşleri

\begin{tabular}{|c|c|c|c|c|c|c|c|}
\hline Ölçek & Faktör & $\begin{array}{l}\text { Okul Dişındaki Bir } \\
\text { Kütüphaneye } \\
\text { Gitmek }\end{array}$ & $\mathrm{N}$ & $\overline{\mathrm{X}}$ & SD & $\mathrm{t}$ & $\mathrm{P}$ \\
\hline \multirow{6}{*}{$\begin{array}{l}\text { Kitap } \\
\text { Okuma } \\
\text { Tutum } \\
\text { Ölçeği }\end{array}$} & \multirow{2}{*}{$\begin{array}{l}\text { Kişisel/Toplumsal } \\
\text { Gelişime Katkı }\end{array}$} & Evet, gittim. & 225 & 3,81 & 0,785 & \multirow{2}{*}{3,881} & \multirow{2}{*}{$0,000^{* *}$} \\
\hline & & Hayır, gitmedim. & 239 & 3,52 & 0,836 & & \\
\hline & \multirow{2}{*}{ İlgi ve Sevmek } & Evet, gittim. & 225 & 3,31 & 0,837 & \multirow{2}{*}{3,701} & \multirow{2}{*}{$0,000^{* *}$} \\
\hline & & Hayır, gitmedim. & 239 & 3,02 & 0,827 & & \\
\hline & \multirow{2}{*}{$\begin{array}{l}\text { Önemli-Değerli } \\
\text { Bulma }\end{array}$} & Evet, gittim. & 225 & 3,23 & 1,046 & \multirow{2}{*}{3,947} & \multirow{2}{*}{$0,000^{* *}$} \\
\hline & & Hayır, gitmedim. & 239 & 2,85 & 1,041 & & \\
\hline \multirow{2}{*}{\multicolumn{2}{|c|}{$\begin{array}{c}\text { Kitap Okumanın Değerlere } \\
\text { Etkisi Ölçeği }\end{array}$}} & Evet, gittim. & 225 & 3,64 & 0,991 & \multirow{2}{*}{2,680} & \multirow{2}{*}{$0,008^{* *}$} \\
\hline & & Hayır, gitmedim. & 239 & 3,48 & 1,050 & & \\
\hline
\end{tabular}

$\mathrm{P}<0,01$

Öğrencilerin okul dışındaki bir kütüphaneye gitme durumlarına göre kitap okuma tutumları analiz edildiğinde ölçeğin tüm faktörlerinde gruplar arasında anlamlı düzeyde farklılık olduğu $(\mathrm{t}=3,381, \mathrm{P}<0,01$; $\mathrm{t}=3,701, \mathrm{P}<0,01 ; \mathrm{t}=3,947, \mathrm{P}<0,01)$ görülmektedir. Kişisel ve toplumsal gelişime katkı faktöründe okul dışındaki bir kütüphaneye giden öğrenciler $\bar{X}=3,81$ puanla değerlendirirlerken, okul dişındaki bir kütüphaneye gitmeyen öğrenciler $\bar{X}=3,52$ puanla değerlendirmişlerdir. Kitap okumaya ilgi ve sevgi duyma bulma faktöründe okul dışındaki bir kütüphaneye giden öğrenciler $\overline{\mathrm{X}}=3,31$ puanla değerlendirirlerken, okul dışındaki bir kütüphaneye gitmeyen öğrenciler $\bar{X}=3,02$ puanla değerlendirmişlerdir. Kitap okumayı önemli ve değerli bulma faktöründe okul dışındaki bir kütüphaneye giden öğrenciler $\bar{X}=3,23$ puanla değerlendirirlerken, okul dişındaki bir kütüphaneye gitmeyen öğrenciler $\overline{\mathrm{X}}=2,85$ puanla değerlendirmişlerdir.

Okul dışındaki bir kütüphaneye gitme durumlarına göre öğrencilerin kitap okumanın değerlere etkisine yönelik görüşleri analiz edildiğinde okul dişındaki bir kütüphaneye giden öğrenciler lehine anlamlı düzeyde bir farklılık olduğu $(\mathrm{t}=2,680, \mathrm{P}<0,01)$ görülmektedir. 
A. KOÇ / Investigation of the Relationship between Attitudes of Students' Reading Book and the Effect of Reading Books on the Values in the RCMK Curriculum I 305

Okul dışındaki bir kütüphaneye giden öğrenciler ölçeği, $\bar{X}=3,64$ puanla değerlendirirlerken, okul dişındaki bir kütüphaneye gitmeyen öğrenciler $\bar{X}=3,48$ puanla orta düzeyde değerlendirmişlerdir. Buna göre, okul dışındaki bir kütüphaneye giden öğrencilerin kitap okumanın değerleri etkilediğine yönelik görüşleri, gitmeyen öğrencilere göre daha yüksek düzeydedir. Bu iki sonucun sebebi, okul dişındaki bir kütüphaneye giden öğrencilerin kitaba olan ilgi, sevgi ve meraklarının daha fazla olması ile açıklanabilir. Ayrıca şimdiye kadar okul dışındaki bir kütüphaneye gitmeyen öğrencilerin $(\mathrm{N}=239, \% 51,5)$ giden öğrencilerden daha fazla olması, eğitimcilerin, araştırmacıların ve ebeveynlerin üzerine eğilmesi gereken bir konu olduğunu göstermektedir. Ortaokul öğrencileriyle yapılan iki ayrı araştırmada da bu araştırmadaki sonuca benzer sonuçlar ortaya konulmuştur. Araştırmaların birinde öğrencilerin yarısının (\%49,7) (Deniz, 2015, 56), diğerinde ise büyük çoğunluğunun (\%61.7) halk kütüphanelerini kullanmadıkları tespit edilmiştir (Tonka, 2020, 41).

\subsection{Ders Kitabı Dışında Bir Kitap Alma Durumuna Göre} Öğrencilerin Kitap Okuma Tutumları ve Kitap Okumanın Değerlere Etkisine Yönelik Görüşleri

Öğrencilerin ders kitabı dışında bir kitap alma durumlarına göre kitap okuma tutumlarını ve kitap okumanın değerlere etkisine yönelik görüşlerini gösteren veriler Tablo 11'de sunulmuştur:

Tablo 11. Ders Kitabı Dışında Bir Kitap Alma Durumlarına Göre Öğrencilerin Kitap Okuma Tutumları ve Kitap Okumanın Değerlere Etkisine Yönelik Görüşleri

\begin{tabular}{|c|c|c|c|c|c|c|c|}
\hline Ölçek & Faktör & $\begin{array}{l}\text { Ders Kitabı } \\
\text { Dişında Bir } \\
\text { Kitap Almak }\end{array}$ & $\mathrm{N}$ & $\overline{\mathrm{X}}$ & SD & $\mathrm{t}$ & $\mathrm{P}$ \\
\hline \multirow{6}{*}{$\begin{array}{l}\text { Kitap } \\
\text { Okuma } \\
\text { Tutum } \\
\text { Ölçeği }\end{array}$} & \multirow{2}{*}{$\begin{array}{l}\text { Kişisel/Toplumsal } \\
\text { Gelişime Katk1 }\end{array}$} & Evet, aldim. & 377 & 3,76 & 0,780 & \multirow{2}{*}{5,288} & \multirow{2}{*}{$0,000^{* *}$} \\
\hline & & Hayır, almadım. & 87 & 3,25 & 0,883 & & \\
\hline & \multirow{2}{*}{ İlgi ve Sevmek } & Evet, aldım. & 377 & 3,24 & 0,851 & \multirow{2}{*}{4,333} & \multirow{2}{*}{$0,000^{* *}$} \\
\hline & & Hayır, almadım. & 87 & 2,82 & 0,715 & & \\
\hline & \multirow{2}{*}{$\begin{array}{l}\text { Önemli-Değerli } \\
\text { Bulma }\end{array}$} & Evet, aldım. & 377 & 3,15 & 1,048 & \multirow{2}{*}{5,007} & \multirow{2}{*}{$0,000^{* *}$} \\
\hline & & Hayır, almadım. & 87 & 2,53 & 0,964 & & \\
\hline \multirow{2}{*}{\multicolumn{2}{|c|}{$\begin{array}{c}\text { Kitap Okumanın Değerlere } \\
\text { Etkisi Ölçeği }\end{array}$}} & Evet, aldim. & 377 & 3,60 & 1,003 & \multirow{2}{*}{4,233} & \multirow{2}{*}{$0,000^{* *}$} \\
\hline & & Hayır, almadım. & 87 & 3,09 & 1,040 & & \\
\hline
\end{tabular}

$\mathrm{P}<0,01$ 
306 | A. KOÇ / Öğrencilerin Kitap Okuma Tutumları ile Kitap Okumanın DKAB Öğretim Programındaki Değerlere Etkisi Arasındaki İlişkinin İncelenmesi

Öğrencilerin ders kitabı dışında bir kitap alma durumlarına göre kitap okuma tutumları analiz edildiğinde ölçeğin tüm faktörlerinde gruplar arasında anlamlı düzeyde farklılık olduğu $(\mathrm{t}=5,288, \mathrm{P}<0,01$; $\mathrm{t}=4,333, \mathrm{P}<0,01 ; \mathrm{t}=5,007, \mathrm{P}<0,01)$ görülmektedir. Kişisel ve toplumsal gelişime katkı faktöründe ders kitabı dışında bir kitap alan öğrenciler $\overline{\mathrm{X}}=3,76$ puanla değerlendirirlerken, ders kitabı dişında bir kitap almayan öğrenciler $\bar{X}=3,25$ puanla değerlendirmişlerdir. Kitap okumaya ilgi ve sevgi duyma bulma faktöründe ders kitabı dışında bir kitap alan öğrenciler $\overline{\mathrm{X}}=3,24$ puanla değerlendirirlerken, ders kitabı dışında bir kitap almayan öğrenciler $\overline{\mathrm{X}}=2,82$ puanla değerlendirmişlerdir. Kitap okumayı önemli ve değerli bulma faktöründe ders kitabı dışında bir kitap alan öğrenciler $\bar{X}=3,15$ puanla değerlendirirlerken, ders kitab1 dişında bir kitap almayan öğrenciler $\bar{X}=2,53$ puanla değerlendirmişlerdir. Ders kitabı dışında bir kitap alma durumlarına göre öğrencilerin kitap okumanın değerlere etkisine yönelik görüşleri analiz edildiğinde ders kitabı dışında bir kitap alan öğrenciler lehine anlamlı düzeyde bir farklılık olduğu $(\mathrm{t}=4,233, \mathrm{P}<0,01)$ görülmektedir. Ders kitabı dışında bir kitap alan öğrenciler ölçeği, $\bar{X}=3,60$ puanla yüksek düzeyde değerlendirirlerken, ders kitabı dışında bir kitap almayan öğrenciler $\bar{X}=3,09$ puanla orta düzeyde değerlendirmişlerdir. Buna göre, ders kitabı dışında bir kitap alan öğrencilerin kitap okumanın değerleri etkilediğine yönelik görüşleri, almamış olan öğrencilere göre daha yüksek düzeydedir. Bu iki sonucun sebebi, ders kitabı dışında bir kitap alan öğrencilerin kitaba olan ilgi, sevgi ve meraklarının daha fazla olması ile açıklanabilir. Ortaokul öğrencilerine yapılan bir araştırmada ise öğrencilerin kitapçılara nadiren gittikleri, bununla ilişkili olarak öğrencilerin boş zamanlarını nadiren kitap okuyarak geçirdikleri ve araştırmaya katılan öğrencilerin yarıdan fazlasının hiç kitap okumadığı ifade edilmektedir (Tüzer, 2016, 53).

\subsection{Dijital Dergi/Kitap Okuma Durumuna Göre Öğrencilerin Kitap Okuma Tutumları ve Kitap Okumanın Değerlere Etkisine Yönelik Görüşleri}

Öğrencilerin dijital dergi/kitap okuma durumlarına göre kitap okuma tutumlarını ve kitap okumanın değerlere etkisine yönelik görüşlerini gösteren veriler Tablo 12'de sunulmuştur: 
A. KOÇ / Investigation of the Relationship between Attitudes of Students' Reading Book and the Effect of Reading Books on the Values in the RCMK Curriculum I 307

Tablo 12. Dijital Dergi/Kitap Okuma Durumlarına Göre Öğrencilerin Kitap Okuma Tutumları ve Kitap Okumanın Değerlere Etkisine Yönelik Görüşleri

\begin{tabular}{|c|c|c|c|c|c|c|c|}
\hline Ölçek & Faktör & $\begin{array}{l}\text { Dijital Dergi/Kitap } \\
\text { Okumak }\end{array}$ & $\mathrm{N}$ & $\overline{\mathrm{X}}$ & SD & $\mathrm{t}$ & $\mathrm{P}$ \\
\hline \multirow{4}{*}{$\begin{array}{l}\text { Kitap } \\
\text { Okuma } \\
\text { Tutum }\end{array}$} & \multirow{2}{*}{$\begin{array}{l}\text { Kişisel/Toplumsal } \\
\text { Gelişime Katkı }\end{array}$} & Evet, okudum. & 261 & 3,87 & 0,755 & \multirow{2}{*}{6,438} & \multirow{2}{*}{$0,000^{* *}$} \\
\hline & & Hayır, okumadım. & 203 & 3,40 & 0,832 & & \\
\hline & \multirow{2}{*}{ İlgi ve Sevmek } & Evet, okudum. & 261 & 3,33 & 0,786 & \multirow{2}{*}{5,068} & \multirow{2}{*}{$0,000^{* *}$} \\
\hline & & Hayır, okumadım. & 203 & 2,94 & 0,865 & & \\
\hline \multirow[t]{2}{*}{ Ölçeği } & Önemli-Değerli & Evet, okudum. & 261 & 3,12 & 1,035 & \multirow{2}{*}{2,114} & \multirow{2}{*}{$0,035^{*}$} \\
\hline & Bulma & Hayır, okumadım. & 203 & 2,91 & 1,082 & & \\
\hline \multirow{2}{*}{\multicolumn{2}{|c|}{$\begin{array}{c}\text { Kitap Okumanın Değerlere } \\
\text { Etkisi Ölçeği }\end{array}$}} & Evet, okudum. & 261 & 3,65 & 0,984 & \multirow{2}{*}{3,468} & \multirow{2}{*}{$0,001^{* *}$} \\
\hline & & Hayır, okumadim. & 203 & 3,32 & 1,056 & & \\
\hline
\end{tabular}

$\mathrm{P}<0,05 ; \mathrm{P}<0,01$

Öğrencilerin dijital dergi/kitap okuma durumlarına göre kitap okuma tutumları analiz edildiğinde ölçeğin tüm faktörlerinde gruplar arasında anlamlı düzeyde farkl1lı olduğu $(\mathrm{t}=6,438, \mathrm{P}<0,01 ; \mathrm{t}=5,068$, $\mathrm{P}<0,01 ; \mathrm{t}=2,114, \mathrm{P}<0,05)$ görülmektedir. Kişisel ve toplumsal gelişime katkı faktöründe dijital dergi/kitap okuyan öğrenciler $\bar{X}=3,87$ puanla değerlendirirlerken, dijital dergi/kitap okumayan öğrenciler $\bar{X}=3,40$ puanla değerlendirmişlerdir. Kitap okumaya ilgi ve sevgi duyma bulma faktöründe dijital dergi/kitap okuyan öğrenciler $\bar{X}=3,33$ puanla değerlendirirlerken, dijital dergi/kitap okumayan öğrenciler $\overline{\mathrm{X}}=2,94$ puanla değerlendirmişlerdir. Kitap okumayı önemli ve değerli bulma faktöründe dijital dergi/kitap okuyan öğrenciler $\overline{\mathrm{X}}=3,12$ puanla değerlendirirlerken, dijital dergi/kitap okumayan öğrenciler $\overline{\mathrm{X}}=2,91$ puanla değerlendirmişlerdir. Dijital dergi/kitap okuma durumlarına göre öğrencilerin kitap okumanın değerlere etkisine yönelik görüşleri analiz edildiğinde dijital dergi/kitap okuyan öğrenciler lehine anlamlı düzeyde bir farkllık olduğu $(\mathrm{t}=3,468, \mathrm{P}<0,01)$ görülmektedir. Dijital dergi/kitap okuyan öğrenciler ölçeği, $\bar{X}=3,65$ puanla yüksek düzeyde değerlendirirlerken, dijital dergi/kitap okumayan öğrenciler $\bar{X}=3,32$ puanla orta düzeyde değerlendirmişlerdir. Buna göre, dijital dergi/kitap okuyan öğrencilerin kitap okumanın değerleri etkilediğine yönelik görüşleri, gitmeyen öğrencilere göre daha yüksek düzeydedir. 
308 | A. KOÇ / Öğrencilerin Kitap Okuma Tutumları ile Kitap Okumanın DKAB Öğretim Programındaki Değerlere Etkisi Arasındaki İlişkinin İncelenmesi

Ayrıca araştırmada öğrencilere sahip oldukları teknolojik araçların neler olduğu sorulmuş ve \%97'sinin akıllı telefon veya tablet sahibi olduğu sonucu elde edilmiştir. Bununla birlikte dijital dergi/kitap okumayan öğrencilerin katılımcıların yarısına yakınını $(\mathrm{N}=203, \% 43,7)$ oluşturması öğrencilerin teknolojik araçları okuma amaçlı kullanmadıklarını göstermektedir. Bu sonuç, öğrencilerin e-kitap okuma tutumlarının düşük olduğunu göstermektedir. Ortaokul ve lise öğrencilerine yapılan iki ayrı araştırmada, genel olarak öğrencilerin ekitap okumak için kullanabilecekleri teknolojik araç-gereçlere sahip olmalarına rağmen e-kitap okumaya dönük tutumlarının düşük olduğu (Çelik, 2015, 284), dolayısıyla öğrencilerin interneti ve teknolojik araçgereçleri kitap okuma amaçlı kullanmadıkları ortaya konulmaktadır (İş̧̧an vd., 2013, 13).

\subsection{2 Öğrencilerin Kitap Okuma Tutumları ile Kitap Okumanın}

\section{Değerlere Etkisine Yönelik Görüşleri Arasındaki İlişki}

Öğrencilerin kitap okuma tutumları ile kitap okumanın değerlere etkisine yönelik görüşleri arasında ilişki olup olmadığını belirlemek için yapılan korelasyon sonuçları Tablo $13^{\prime}$ te sunulmuştur:

Tablo 13. Öğrencilerin Kitap Okuma Tutumları ile Kitap Okumanın Değerlere Etkisine Yönelik Görüssleri Arasındaki İlişkiye Ait Korelasyon

\begin{tabular}{|c|c|c|c|c|c|}
\hline & & $\begin{array}{c}\text { Kişisel/ } \\
\text { Toplumsal } \\
\text { Gelişime Katk1 }\end{array}$ & $\begin{array}{l}\text { İlgi ve } \\
\text { Sevmek }\end{array}$ & $\begin{array}{l}\text { Önemli- } \\
\text { Değerli } \\
\text { Bulma }\end{array}$ & $\begin{array}{l}\text { Kitap Okumanın } \\
\text { Değerlere Etkisi }\end{array}$ \\
\hline \multirow{2}{*}{$\begin{array}{l}\text { Kişisel/Toplumsal } \\
\text { Gelişime Katkı }\end{array}$} & Pearson & 1 & $0,662^{* *}$ & $0,215^{* *}$ & $0,748^{* *}$ \\
\hline & $\begin{array}{l}\text { Sig. (2- } \\
\text { tailed) }\end{array}$ & & 0,000 & 0,000 & 0,000 \\
\hline \multirow[b]{2}{*}{ İlgi ve Sevmek } & Pearson & $0,662^{* *}$ & 1 & $0,508^{* *}$ & $0,599^{* *}$ \\
\hline & $\begin{array}{l}\text { Sig. (2- } \\
\text { tailed) }\end{array}$ & 0,000 & 0,000 & 0,000 & 0,000 \\
\hline \multirow{2}{*}{$\begin{array}{l}\text { Önemli-Değerli } \\
\text { Bulma }\end{array}$} & Pearson & $0,215^{* *}$ & $0,508^{* *}$ & 1 & $0,207^{* *}$ \\
\hline & $\begin{array}{l}\text { Sig. }(2- \\
\text { tailed) }\end{array}$ & 0,000 & 0,000 & 0,000 & 0,000 \\
\hline \multirow{3}{*}{$\begin{array}{l}\text { Kitap Okumanın } \\
\text { Değerlere Etkisi }\end{array}$} & Pearson & $0,748^{* *}$ & $0,599^{* *}$ & $0,207^{* *}$ & 1 \\
\hline & $\begin{array}{l}\text { Sig. }(2- \\
\text { tailed) }\end{array}$ & 0,000 & 0,000 & 0,000 & \\
\hline & $\mathrm{N}$ & 464 & 464 & 464 & 464 \\
\hline
\end{tabular}

$\mathrm{P}<0,01$ 
A. KOÇ / Investigation of the Relationship between Attitudes of Students' Reading Book and the Effect of Reading Books on the Values in the RCMK Curriculum I 309

Tablo 13'te verilen korelasyon sonuçlarına göre öğrencilerin kitap okuma tutumları ile kitap okumanın değerlere etkisine yönelik görüşleri arasında pozitif ve anlamlı bir ilişki olduğu, bu ilişkinin bir boyutta yüksek, bir boyutta orta ve bir boyutta düşük düzeyde olduğu görülmektedir. Çünkü korelasyon katsayısının, mutlak değer olarak 0,70 ile 1,00 arasında olması yüksek; 0,70 ile 0,30 arasında olması orta ve 0,30 ile 0,00 arasında olması düşük düzeyde bir ilişki olduğu şeklinde yorumlanmaktadır (Büyüköztürk, 2020, 32). Öğrencilerin kitap okumanın değerlere etkisine yönelik görüşleri ile kitap okuma tutum ölçeğinin tüm boyutları arasında pozitif yönlü bir ilişki ( $r=748, r=599$, $\mathrm{r}=207 ; \mathrm{P}<0,01)$ vardır. Buna göre kitap okuma tutumları arttıkça kitap okumanın değerleri etkilediğine yönelik görüsslerinin de arttı̆̆ını söylemek mümkündür. Determinasyon katsayıları $\left(r^{2}=0,55, \quad r^{2}=0,35\right.$, $\left.\mathrm{r}^{2}=0,04\right)$ dikkate alındığında; kitap okuma tutumunun kişisel ve toplumsal gelişime katkısı boyutundaki toplam değişkenliğin \%55'inin, ilgi ve sevmek boyutundaki toplam değişkenliğin \%35'inin ve önemli/değerli bulma boyutundaki toplam değişkenliğin \%4'ünün öğrencilerin kitap okumanın değerlere etkisine yönelik görüşlerinden kaynaklandığı söylenebilir. Bu sonuçlara göre öğrencilerin kitap okumanın değerlere etkisinin olumlu olacağına yönelik görüşlerinin, onların kitap okuma tutumları üzerinde pozitif katkısı olduğu söylenebilir.

\section{Sonuç}

KKTC'deki ortaokul ve liselerde eğitim gören öğrencilerin kitap okuma tutumları ile kitap okumanın DKAB öğretim programında üzerinde en sık durulan değerler olan "adalet, duyarlılık, dayanışma, merhamet, nezaket, dürüstlük, sabır, sevgi, saygl, sorumluluk ve yardımlaşma" değerlerine etkisine yönelik görüşlerinin incelendiği bu araştırmada şu sonuçlara ulaşılmıştır:

KKTC'nin beş ayrı ilçesinde ve yedi ayrı okul türündeki öğrencilerle gerçekleştirilen bu araştırmada; öğrencilerin \%15,9'unun hiç kitap okumayan, \%51,2'sinin az kitap okuyan özelliğinde olmalarına rağmen kitap okumanın "kişisel/toplumsal gelişimlerine katkı sağlama" faktöründe yüksek düzeyde, "ilgi/sevgi duyma" ile "önemli/değerli bulma" faktörlerinde orta düzeyde tutuma sahip oldukları tespit edilmiştir. Öğrencilerin kitap okumanın değerlere etkisine yönelik görüşleri ise yüksek düzeydedir. Bu sonuçlara göre öğrencilerin her ne kadar hiç 
310 | A. KOÇ / Öğrencilerin Kitap Okuma Tutumları ile Kitap Okumanın DKAB Öğretim Programındaki Değerlere Etkisi Arasındaki İlişkinin İncelenmesi

kitap okumasalar da veya az kitap okusalar da kitap okumanın kişisel/toplumsal gelişimlerine katkı sağlayacağını ve değerlere etkisinin de olumlu olacağını düşündükleri söylenebilir.

Cinsiyet değişkenine göre veriler analiz edildiğinde kadın öğrencilerin kitap okuma tutumlarının erkek öğrencilere göre daha yüksek olduğu tespit edilmiştir. Öğrencilerin kitap okumanın değerlere etkisine yönelik görüşleri ise cinsiyet değişkenine göre farklılık göstermemektedir. Hem kadın hem de erkek öğrencilerin bu konudaki tutumları yüksek düzeydedir.

Okul türü değişkenine göre veriler analiz edildiğinde kitap okumanın "kişisel/toplumsal gelişime katkısı" ve kitap okumayı "önemli/değerli bulma" faktörlerinde ve kitap okumanın değerlere etkisi ölçeğinde, Anadolu Lisesi, İlahiyat Koleji/Lisesi ve Kolej öğrencilerinin diğer öğrencilerden daha yüksek bir kitap okuma tutumuna sahip oldukları tespit edilmiştir. Özellikle akademik başarı ile kitap okuma arasındaki pozitif ilişkinin bu sonucun sebebi olduğu söylenebilir. Çünkü bu okullar öğrencilerini seçme sınavı ile almakta ve genel anlamda öğrencilerinin bir önceki okula ait diploma notlarının daha yüksek olduğu görülmektedir. Kitap okumaya "ilgi/sevgi duyma" faktöründe ise İlahiyat Koleji/Lisesi öğrencilerinin diğer okullardaki öğrencilerden daha yüksek bir tutuma sahip oldukları tespit edilmiştir. Okuldaki kitap okuma etkinliklerinin, yarışmaların ve kütüphaneye erişimin kolay olmasının İlahiyat Koleji/Lisesi öğrencilerinin kitaba ilgi ve sevgi duymalarında rol oynadığı söylenebilir.

Sınıf seviyesi değişkenine göre veriler analiz edildiğinde öğrencilerin kitap okuma tutumlarının ortaokul ve lise düzeyinde olmalarına bağlı olarak değişmediği tespit edilmiştir. Kitap okumanın değerlere etkisine yönelik veriler analiz edildiğinde, bu ölçeği, ortaokul öğrencilerinin daha yüksek puanlarla değerlendirdikleri tespit edilmiştir. Bunun sebebi, ergenlik dönemindeki ortaokul öğrencilerinin kişilik ve karakter gelişim dönemlerinde olmasına bağlı olarak bunu daha fazla hissetmeleri ile açıklanabilir.

Evinde çalışma odası ve kitaplık/kitap köşesi olması değişkenlerine göre veriler analiz edildiğinde evlerinde çalışma odası ve kitaplık/kitap köşesi olan öğrencilerin hem kitap okuma tutumlarının hem de kitap okumanın değerlere etkisine yönelik görüşlerinin daha yüksek olduğu tespit edilmiştir. Bunun sebebi, evinde çalışma odası ve 
A. KOÇ / Investigation of the Relationship between Attitudes of Students' Reading Book and the Effect of Reading Books on the Values in the RCMK Curriculum I 311 kitaplık/kitap köşesi olan öğrencilerin kitap okuma ortamını daha uygun şartlarda yaşamaları ile açılanabilir.

Yılda okudukları kitap sayısına göre veriler analiz edildiğinde öğrencilerin \%15,9'unun yılda hiç kitap okumadığı, \%51,2'sinin az kitap okuduğu, 24,2'sinin orta düzeyde bir okuyucu olduğu ve $\% 8,7^{\prime}$ sinin çok okuyan grubunda olduğu görülmektedir. Öğrencilerin kitap okuma tutumları ve kitap okumanın değerlere etkisine yönelik görüşlerinin okudukları kitap sayısına göre değişip değişmediğine bakıldığında, orta düzey ve çok okuyan grubundaki öğrencilerin hem kitap okuma tutumlarının hem de kitap okumanın değerlere etkisine yönelik görüşlerinin daha yüksek olduğu tespit edilmiştir. Bunun doğal bir sonuç olduğu ve öğrencilerin kitap okudukça bunun bir tutku haline geldiği, değerlerinin de bu durumdan olumlu etkilendiğini düşündükleri söylenebilir.

Okul kütüphanesinden kitap alma değişkenine göre veriler analiz edildiğinde öğrencilerin $\% 62,7^{\prime}$ sinin okul kütüphanesinden kitap aldığ1 tespit edilmiştir. Bir eğitim ve okuma yuvası olan okullarda en az altı senedir okuyan öğrencilerden \%37,3'ünün ise henüz okul kütüphanesinden bir kitap almadığı tespit edilmiştir. Okul kütüphanesinden kitap alan öğrencilerin hem kitap okuma tutumlarının hem de kitap okumanın değerlere etkisine yönelik görüşlerinin daha yüksek olduğu tespit edilmiştir. Bunun sebebi, kitaba erişimlerinin kolay olmasına bağlanabilir.

Okul dışındaki bir kütüphaneye gitme değişkenine göre veriler analiz edildiğinde öğrencilerin yarıdan fazlasının (\%51,5) okul dışında bir kütüphaneye gitmediği tespit edilmiştir. Okul dışında bir kütüphaneye giden öğrencilerin hem kitap okuma tutumlarının hem de kitap okumanın değerlere etkisine yönelik görüşlerinin daha yüksek olduğu tespit edilmiştir. Bunun sebebi, kitap okuma ile sosyal aktiviteyi birleştirmelerinin sonucu olarak kitap okumanın daha zevkli hale gelmesi ile açılanabilir.

Ders kitabı dışında bir kitap alma değişkenine göre veriler analiz edildiğinde öğrencilerin büyük çoğunluğunun $(\% 81,2)$ ders kitabı dışında bir kitap aldığı tespit edilmiştir. Ders kitabı dışında bir kitap alan öğrencilerin hem kitap okuma tutumlarının hem de kitap okumanın değerlere etkisine yönelik görüşlerinin daha yüksek olduğu tespit edilmiştir. Bunun sebebi olarak, kendilerine ait bir kitabın 
312 | A. KOÇ / Öğrencilerin Kitap Okuma Tutumları ile Kitap Okumanın DKAB Öğretim Programındaki Değerlere Etkisi Arasındaki İlişkinin İncelenmesi

olmasının hem öğrencilerin okumaya olan ilgilerini arttırmasıyla hem de kitaplarını sahiplenmeleriyle açıklanabilir.

Dijital dergi/kitap okuma değişkenine göre veriler analiz edildiğinde öğrencilerin 56,3'ünün dijital dergi/kitap okuduğu tespit edilmiştir. Katılımcıların \%97'sinin akıllı telefon ya da tablet/bilgisayar sahibi olduklarını beyan ettikleri dikkate alınırsa, \%43,7'sinin henüz dijital dergi/kitap okumaması, teknolojiyi ve interneti okuma amaçlı kullanmadıkları sonucunu ortaya çıkarmaktadır. Dijital dergi/kitap okuyan öğrencilerin hem kitap okuma tutumlarının hem de kitap okumanın değerlere etkisine yönelik tutumlarının daha yüksek olduğu tespit edilmiştir. Bunun sebebi, akıllı telefon/tablet/bilgisayar aracılığıyla okumayı eğlenceli bulmaları, kitap ve dergilere kolay erişebilmeleri şeklinde açıklanabilir.

Öğrencilerin kitap okuma tutumları ile kitap okumanın değerlere etkisine yönelik görüşleri arasında pozitif ve anlamlı bir ilişki olduğu tespit edilmiştir. Buna göre öğrencilerin kitap okuma tutumları arttıkça kitap okumanın değerleri etkilediğine yönelik görüşlerinin de arttı̆̆ını söylemek mümkündür. Ayrıca aralarındaki pozitif ilişkiye bağlı olarak öğrencilerin kitap okumanın değerlere etkisinin olacağına yönelik görüşlerinin, onların kitap okuma tutumları üzerinde pozitif katkısının olduğu da söylenebilir.

Bu sonuçlara göre şu önerilerde bulunabilir:

Öğrencilerin kitap okumaya yönelik olumlu duygu ve düşünceleri olsa da kitap okuma alışkanlıklarının oldukça düşük olduğu görülmüştür. Bunun giderilmesine yönelik okullarda kitap okuma projeleri, etkinlikleri ve yarışmaları düzenlenebilir.

Öğretmenlerin ve anne-babaların kitap okuma ile ilgili nasihat yerine yaşam boyu öğrenme çerçevesinde beraber okuyarak rol model olmaları öğrencilerin kitap okuma tutumlarına olumlu katkı sağlayacaktır.

Kitap okumanın değerleri etkilediğine yönelik ortaya çıkan bu araştırmadaki sonuç dikkate alınarak öğrencilere yaşlarına uygun olarak seçilecek kitaplarla milli-manevi değerler kazandırılabilir.

Evdeki çalışma odası/kitaplık/kitap köşesine sahip olmanın kitap okuma tutumunu olumlu etkilediği dikkate alınarak evlerde bu yönde tedbirler alınabilir. 
A. KOÇ / Investigation of the Relationship between Attitudes of Students' Reading Book and the Effect of Reading Books on the Values in the RCMK Curriculum I 313

Önemli sayıdaki bir öğrenci grubunun henüz okul kütüphanesinden kitap almadığı düşünüldüğünde okullarda tüm öğrencilerin kütüphaneyi kullanmaları ve kitap almaları için etkinlik ve projeler yürütülebilir.

Öğrencilerin yarıdan fazlasının okul dişındaki bir kütüphaneye gitmediği dikkate alınarak aile fertleriyle ve/veya okul/sınıf olarak kütüphane ziyaretleri yapılabilir.

Öğrencilerin yarısına yakınının interneti ve teknolojiyi okuma amaçlı kullanmadıkları tespit edildiğinden öğretmenler, çeşitli ödev ve projeleri dijital kitap/dergi/makale okumaları üzerinden verebilir.

Öğrencilerin kitap okuma tutumlarının ve kitap okumanin değerlere etkisinin incelendiği bu araştırmanın benzeri farklı örneklemler seçilerek uygulanabilir. Ayrıca kitap okumanın hangi değerleri, nasıl etkilediğini ortaya koymak için nitel araştırmalar yapilabilir.

\section{Kaynakça}

Arı, Gökhan. "Türkçe Ders Kitaplarındaki Fiziksel ve Biçimsel Görünüm”. Türkçe Ders Kitabı Çözümlemeleri. ed. Hakan Ülper. 3955. Ankara: Pegem Akademi Yayıncilık, 3. Basım, 2014.

Arslan, Aysel - Bıçakçıgil Özsoy, Rahime. "Meslek Yüksekokulu Öğrencilerinin Yaşam Boyu Öğrenme Eğilimleri ve Kitap Okuma Alışkanlıklarına İlişkin Tutumlarının İncelenmesi". Journal of International Social Research 12/66 (Ekim 2019), 730-747. https://doi.org/10.17719/jisr.2019.3622.

Balcı, Ahmet. "İlkögretim 8. Sınıf Öğrencilerinin Kitap Okuma Alışkanlığına Yönelik Tutumları". Mustafa Kemal Üniversitesi Sosyal Bilimler Enstitüsü Dergisi 6/11 (2009), 265-300.

Baş, Gökhan - Bayhan, Ömer. “Türkiye'de Değerler Eğitimi Konusunda

Yapılmış Lisansüstü Tezlerin Farklı Değişkenler Açısından Değerlendirilmesi". Değerler Eğitimi Dergisi 10/24 (2012), 55-74.

Bulut, Pınar vd.. "Okuma Kültürü Üzerine Bir İnceleme: Öğretmen Adayları Örneği". Gençlik Araştırmaları Dergisi 8/21 (2020), 74-95.

Büyüköztürk, Şener vd.. Bilimsel Araştırma Yöntemleri. Ankara: Pegem

Akademi Yayıncllı, 27. Basım, 2019.

https://doi.org/10.14527/9789944919289. 
314 | A. KOÇ / Öğrencilerin Kitap Okuma Tutumları ile Kitap Okumanın DKAB Öğretim Programındaki Değerlere Etkisi Arasındaki İlişkinin İncelenmesi

Büyüköztürk, Şener. Sosyal Bilimler İçin Veri Analizi Kitabı. Ankara: Pegem Akademi Yayıncilık, 27. Basım, 2020.

Calp, Mehrali. “Ortaokul Öğrencilerinin Kitap Okuma Alışkanlıkları: Ağrı İl Örneği". Türkiye Sosyal Araştırmalar Dergisi 22/3 (2018), 897924.

Çelik, Tuğba. "Öğrencilerin E-Kitap Okuma Tutumlarının İncelenmesi". Journal of Turkish Studies 10/3 (Ocak 2015), 271-284. https://doi.org/10.7827/TurkishStudies.7803.

Demir, Zeynel Abidin. "Ortaöğretim Son Sinıf Öğrencilerinin Kitap Okuma Alışkanlıklarının İncelenmesi -Siirt Örneği-". Siirt: Siirt Üniversitesi, Sosyal Bilimler Enstitüsü, Yüksek Lisans Tezi, 2016.

Deniz, Ercan. “Ortaokul Öğrencilerinin Kitap Okuma Alışkanlıkları”. Okuma Yazma Ĕ̆itimi Araştırmaları 3/2 (2015), 46-64.

Dilbaz, Gözde Hilal. “Ortaokul Öğrencilerinin Okumaya Yönelik Tutumlarının ve Okur Öz-Algılarının Çeşitli Değişkenlere Göre Değerlendirilmesi". Denizli: Pamukkale Üniversitesi, Eğitim Bilimleri Enstitüsü, Yüksek Lisans Tezi, 2019.

Dündar, Hakan - Hareket, Erdem. "Değerler Eğitimi Araştırmalarında Yönelimler: Değerler Eğitimi Dergisi Örneği". Akademik Bakış Dergisi 55 (2016), 207-231.

Elbir, Bilal - Bağcl, Can. "Birinci ve İkinci Kademe Okuma Eğitimi Üzerine Yapılan Lisansüstü Çalışmaların Değerlendirilmesi". Adryaman Üniversitesi Sosyal Bilimler Enstitüsü Dergisi 6/11 (2013), 229-247.

Göksu, Mehmet Zeki. "İmam Hatip Ortaokulları ile Diğer Devlet Ortaokullarının Değerler Eğitimi Açısından Karşılaştırılması". Rize: Recep Tayyip Erdoğan Üniversitesi, Sosyal Bilimler Enstitüsü, Doktora Tezi, 2018.

Gör, Fatih. "İlköğretim Din Kültürü ve Ahlâk Bilgisi Öğretim Programında Merhamet Değeri". Erzurum: Atatürk Üniversitesi, Sosyal Bilimleri Enstitüsü, Yüksek Lisans Tezi, 2013.

Güncel Türkçe Sözlük. Erişim 20 Temmuz 2020. http://sozluk.gov.tr.

Güneş, Adem. "Manevi-insani Değerler Eğilim Ölçeği (Midö): Geçerlik ve Güvenirlik Çalışması." Uluslararası Sosyal Araştırmalar Dergisi 8/41 (2015), 1354-1360.

Güneş, Firdevs - Susar Kırmızı, Fatma. “E-Kitap Okumaya Yönelik Tutum Ölçeğinin (Ekot) Geliştirilmesi: Geçerlilik ve Güvenirlik 
A. KOÇ / Investigation of the Relationship between Attitudes of Students' Reading Book and the Effect of Reading Books on the Values in the RCMK Curriculum। 315

Çalışması". Bartın Üniversitesi Eğitim Fakültesi Dergisi 3/2 (Aralık 2014), 196-212. https://doi.org/10.14686/BUEFAD.201428178.

Güney, Nail vd.. “Dokuzuncu Sınıf Öğrencilerinin Okuduğu Kitap Sayısı ile Akademik Başarıları Arasındaki İlişki Üzerine Bir Değerlendirme". Süleyman Demirel Üniversitesi Sosyal Bilimler Enstitüsü Dergisi 1/19 (2014), 151-165.

İşçan, Adem vd.. "İlköğretim İkinci Kademe Öğrencilerin Kitap Okuma Alışkanlıkları ve Okumaya İlişkin Tutumları". Uluslararası Avrasya Sosyal Bilimler Dergisi 4/11 (2013), 1-16.

Karakullukçu, Necmiye. "İlkokul Öğrencilerine Kitap Okuma Alışkanlığı Kazandırmada Sınıf Öğretmenlerinin Rolü". Samsun: Ondokuz Mayıs Üniversitesi, Eğitim Bilimleri Enstitüsü, Yüksek Lisans Tezi, 2019.

Karatay, Halit vd.. "Okuma Alışkanlığını Geliştirme Yöntem, Teknik ve Modelleri". Okuma Yazma Eğitimi Araştırmaları Dergisi 8/1 (2020), 89-107. https://doi.org/10.35233/oyea.707967.

Keleş, Özgül. "İlköğretim 4 ve 5. Sınıf Öğrencilerinde Kitap Okuma Alışkanlığının İncelenmesi". Ankara: Gazi Üniversitesi, Eğitim Bilimleri Enstitüsü, Yüksek Lisans Tezi, 2006.

KKTCMEY, Kuzey Kıbrıs Türk Cumhuriyeti Milli Eğitim Yasası. 51 (23 Mayıs 1986). http://www.mebnet.net/sites/default/files/yasalar/171986.pdf.

Kulu, Sacide. "Hala Sultan Kitap Okuyor". Gençses Öğrenci Gazetesi (Eylül 2017), 4.

KKTCDKAB, KKTC DKAB Öğretim Programları. “Temel Eğitim Din Kültürü ve Ahlak Bilgisi Dersi Öğretim Programı". 2018. http://talimterbiye.mebnet.net/Ogretim\%20Programlari/20182019/Din.pdf.

Metin, Özge - Metiner, Ayşegül. “Değerler Eğitimi Alanındaki Çalışmaların Eğilimi: USBES Örneği". International Journal of Field Education 5/2 (2019), 72-93.

Sarar Kuzu, Tülay - Doğan, Türkan. "Öğretmen Adaylarina Yönelik Okuma Tutum Ölçeği Geliştirme". Journal of Turkish Studies 10/15 (2015), 771-786. https://doi.org/10.7827/TurkishStudies.8938.

Şahin, Abdullah vd.. “İlköğretim Öğrencilerinin Okul Kütüphaneleri ve Sınıf Kitaplıklarını Kullanma Durumları (Erzurum İli Örneği)". 
316 | A. KOÇ / Öğrencilerin Kitap Okuma Tutumları ile Kitap Okumanın DKAB Öğretim

Programındaki Değerlere Etkisi Arasındaki İlişkinin İncelenmesi

Atatürk Üniversitesi Sosyal Bilimler Enstitüsü Dergisi 13/2 (2009), 183196.

Şahin, Ayfer. “illköğretim 4 ve 5. Sınıf Öğrencilerinin Kitap Okuma Alı̧̧kanlıklarının Sosyo-Ekonomik Düzeylerine Göre İncelenmesi". Türk Ĕ̆itim Bilimleri Dergisi 10/2 (2012), 367-388.

Şahin, Nurullah. “Türkçe Öğretmeni Adaylarının Okuma Motivasyonlarının Çeşitli Değişkenler Açısından İncelenmesi". OPUS Uluslararası Toplum Araştırmaları Dergisi 13/19 (Eylül 2019), 393-423. https://doi.org/10.26466/opus.588759.

Tonka, Hilal. “Ortaokul Öğrencilerinin Kitap Okuma Alışkanlıkları İle Okuma Kaygıları Arasındaki İlişkinin İncelenmesi". Erzurum: Atatürk Üniversitesi, Eğitim Bilimleri Enstitüsü, Yüksek Lisans Tezi, 2020.

TTKB, Talim Terbiye Kurulu Başkanlığı. "Müfredatta Yenileme ve Değişiklik Çalışmalarımız Üzerine". Basın Açıklaması. 18 Temmuz 2017. $\quad$ Erişim $13 \quad$ Temmuz 2020. https://ttkb.meb.gov.tr/meb_iys_dosyalar/2017_07/18160003_basin _aciklamasi-program.pdf.

Türegün, Emre - Kaya, Asll. “Marmara ve İstanbul Üniversiteleri Spor Bilimleri Fakültesi Öğrencilerinin Kitap Okumaya Yönelik Bakış Açlarının Değerlendirilmesi". Türkiye Spor Bilimleri Dergisi 3/1 (Temmuz 2019), 26-32. https://doi.org/10.32706/tusbid.537434.

Tüzer, Ahmet. “Ortaokul Sekizinci Sınıf Öğrencilerinin Okuma Alışkanlıkları ile Sayısal Ders Başarıları Arasındaki İlişkinin İncelenmesi". Kahramanmaraş: Kahramanmaraş Sütçü İmam Üniversitesi, Sosyal Bilimler Enstitüsü, Yüksek Lisans Tezi, 2016.

Yaman, Havva - Süğümlü, Üzeyir. "İlköğretim İkinci Kademe Öğrencilerinin Ders Dışı Kitap Okuma Alışkanlıkları". Kastamonu Eğitim Dergisi 18/1 (2010), 291-306.

Yıldırım, Mehmet - Ceylan, Oğuzhan. "Lise Öğrencilerinin Kitap Okuma Alışkanlıklarının Demografik Özelliklerine Göre Karşılaştırılması (Amasya İli Örneği)". Uluslararası Sosyal Araştırmalar Dergisi 11/55 (Şubat 2018), $734-746$. https://doi.org/10.17719/jisr.20185537245.

Yıldız, Mustafa. “Okuma Motivasyonu, Akıcı Okuma ve Okuduğunu Anlamanın Beşinci Sınıf Öğrencilerinin Akademik Başarılarındaki 
A. KOÇ / Investigation of the Relationship between Attitudes of Students' Reading Book and the Effect of Reading Books on the Values in the RCMK Curriculum I 317

Rolü". Turkish Studies - International Periodical for the Languages, Literature and History of Turkish or Turkic 8/4 (2013), 1461-1478.

Yıldız, Nurettin - Keskin, Harun. “Ergenlik Dönemindeki Öğrencilerin Dijital ve Matbu Okumaya Karşı Tutumlarının Çeşitli Değişkenlere Göre Değerlendirilmesi”. Mersin Üniversitesi Ĕ̆itim Fakültesi Dergisi 12/1 (Nisan 2016), 344-361. https://doi.org/10.17860/efd.82485.

Yurtkoru, E. Serra vd.. Sosyal Bilimlerde SPSS'le Veri Analizi. İstanbul: Beta Basım Yayın, 7. Basım, 2018. 
318 | A. KOÇ / Öğrencilerin Kitap Okuma Tutumları ile Kitap Okumanın DKAB Öğretim

Programındaki Değerlere Etkisi Arasındaki İlişkinin İncelenmesi

Ek: Kitap Okumanın Değerlere Etkisi Ölçeği

\begin{tabular}{|c|c|c|c|c|c|}
\hline $\begin{array}{l}\text { KITAP OKUMANIN DEĞERLERE ETKİSİ } \\
\text { ÖLÇEĞİ } \\
\text { Soruların ölçekleri, } 5 \text { nolu şık en güçlü, } 1 \text { nolu } \\
\text { şık en zayıf olacak şekilde, güçlüden zayıfa } \\
\text { doğru numaralandırılmıştır. Bunu dikkate } \\
\text { alarak cevap vermenizi rica ederim. } \\
\text { Aşağıdaki ifadelerin karşısındaki seçeneklerin } \\
\text { üzerine (X) işareti koyarak görüşünüzü } \\
\text { belirtiniz. } \\
\text { 5. Tamamen katılıyorum. } \\
\text { 4. Çoğunlukla katıllyorum. } \\
\text { 3. Kismen katıllyorum. } \\
\text { 2. Nadiren katıllyorum. } \\
\text { 1. Hiç katılmiyorum. }\end{array}$ & 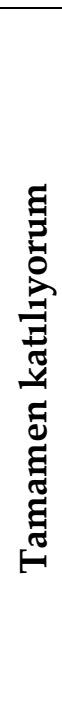 & 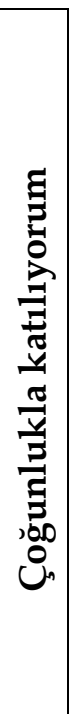 & 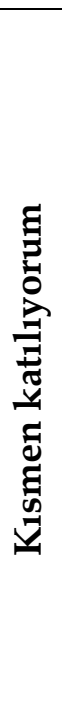 & 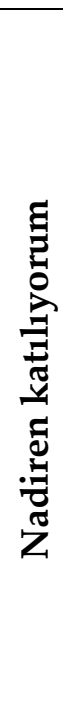 & 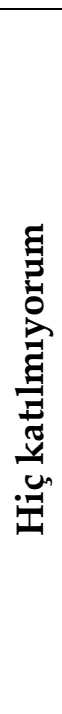 \\
\hline $\begin{array}{l}\text { 1. Düzenli kitap okumak, kişinin } \\
\text { davranışlarında ve aldığı kararlarda daha } \\
\text { adaletli olmasını sağlar. }\end{array}$ & 5 & 4 & 3 & 2 & 1 \\
\hline 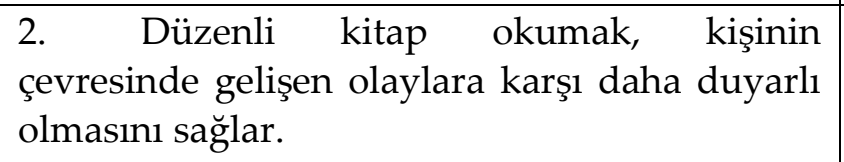 & 5 & 4 & 3 & 2 & 1 \\
\hline $\begin{array}{l}\text { 3. Düzenli kitap } \text { okumak, }^{\text {kişinin }} \\
\text { başkalarıyla yaşadığı problemlerde daha } \\
\text { uzlaşmacı olmasını sağlar. }\end{array}$ & 5 & 4 & 3 & 2 & 1 \\
\hline $\begin{array}{l}4 . \quad \text { Düzenli kitap okumak, kişinin } \\
\text { başkalarının kendisinden farklı düşüncelerine } \\
\text { karşı daha anlayışlı olmasını sağlar. }\end{array}$ & 5 & 4 & 3 & 2 & 1 \\
\hline $\begin{array}{l}\text { 5. Düzenli kitap okumak, } \\
\text { başkalarını eleştirirken } \\
\text { sağlar. }\end{array}$ & 5 & 4 & 3 & 2 & 1 \\
\hline
\end{tabular}


A. KOÇ / Investigation of the Relationship between Attitudes of Students' Reading Book and the Effect of Reading Books on the Values in the RCMK Curriculum I 319

\begin{tabular}{|l|l|l|l|l|l|l|}
\hline $\begin{array}{l}\text { 6. Düzenli kitap okumak, kişinin bilgi ve } \\
\text { yeteneklerini dostlarıla daha çok } \\
\text { paylaşmasını sağlar. }\end{array}$ & 5 & 4 & 3 & 2 & 1 \\
\hline $\begin{array}{l}7 . \quad \text { Düzenli kitap okumak, kişinin } \\
\text { çevresindekilerin dertlerine daha fazla ortak } \\
\text { olabilmesini sağlar. }\end{array}$ & 5 & 4 & 3 & 2 & 1 \\
\hline $\begin{array}{l}8 . \quad \text { Düzenli kitap okumak, kişinin } \\
\text { başkalarını incitmekten daha çok kaçınmasını } \\
\text { sağlar. }\end{array}$ & 5 & 4 & 3 & 2 & 1 \\
\hline $\begin{array}{l}\text { 9. Düzenli kitap okumak, kişinin } \\
\text { sorumluluklarını yerine getirmesi hususunda } \\
\text { daha titiz olmasını sağlar. }\end{array}$ & 5 & 4 & 3 & 2 & 1 \\
\hline $\begin{array}{l}\text { 10. Düzenli kitap okumak, kişinin hakkını } \\
\text { korumak için bile olsa yanlış yollara } \\
\text { sapmamasına katkı sağlar. }\end{array}$ & 5 & 4 & 3 & 2 & 1 \\
\hline
\end{tabular}

